\title{
Growth factors as autocrine and paracrine modulators of male gonadal functions
}

\author{
A. R. Bellvé* and W. Zheng† \\ Departments of *Anatomy and Cell Biology, †Obstetrics and Gynecology, and *Urology, and the \\ * Center for Reproductive Sciences, College of Physicians and Surgeons, Columbia University, \\ 650 West 168th Street, New York, NY 10032, USA
}

Keywords: growth factors; testis

\section{Introduction}

Growth and differentiation of the male gonads involves a complex sequence of interactions between soma and germ cell elements. These interactions are mediated principally by the trophic hormones, FSH, LH, GH and prolactin, and the sensitive autocrine and paracrine actions of growth factors. During fetal and neonatal life, development of the gonads requires the differential expansion of epithelial and mesenchymal tissues to form the interstitial and epithelial compartments, respectively, of the testes (Bellvé \& Feig, 1984). In pubertal and adult animals, the onset and maintenance of spermatogenesis require an exact temporal regulation of germ cell proliferation and differentiation. For both events there must be an array of local growth factors, each interacting with a restricted range of target cells and thereby modulating their rates of proliferation and/or multiple pleiotypic responses. These actions could involve the differential induction of cell proliferation to promote growth of germ cells, epithelial cells and interstitial tissue, and to form essential vascular and lymphatic elements. Such proliferative effects presumably are regulated spatially and temporally during development to ensure the co-ordinated growth of the interstitium and the seminiferous epithelium.

Pleiotypic actions of local testicular growth factors could include modulation of Leydig cell steroidogenesis, with the androgenic steroids providing, in turn, mechanisms for promoting the hormonally sensitive stages of germ cell differentiation. Other pleiotypic effects could be mediated via the peritubular myoid cells and Sertoli cells, with the growth promotor inducing expression of multiple differentiated functions involving the synthesis of specific cellular and secretory proteins. These pleiotypic responses can be expected to change in cyclic patterns to accommodate the continuing needs of ongoing spermatogenesis. It is possible, also, that other growth factors could act directly on germ cells to co-ordinate their proliferation and differentiation. Based on these premises then, the search for local modulators of testicular functions is of considerable importance for revealing novel mechanisms for controlling spermatogenesis.

\section{Patterns of growth during gonadal development}

The proliferation and subsequent differentiation of Sertoli cells is one of the first cytological events of gonad formation and development (Bellvé, 1979). These epithelial cells, after migrating across from the major glomerulus of the mesonephric tubules (Zamboni \& Upadhyay, 1982), proliferate to form the principal constituents of the bilaterally-disposed gonadal anlagen. These Sertoli cell 
precursors continue to proliferate and, along with an interdigitation of cellular processes and the deposition of extracellular material, establish an epithelial polarity to form the primordial seminiferous cords, the progenitors of the seminiferous tubules (Fig. 1) (Magre \& Jost, 1980). These cord-like structures continue to expand in diameter and to elongate throughout the remainder of gestation and during the immediate postnatal period (Huckins \& Clermont, 1968). Later, however, during the prepubertal period, all Sertoli cells cease dividing (Steinberger \& Steinberger, 1971; Nagy, 1972; Orth, 1982), and gradually express an increased number of differentiated functions. Thus, the population of Sertoli cells established during the perinatal period defines the numbers that exist in the pubertal and the adult testes.

Other evidence suggests that the final number of Sertoli cells may be subject to genetic control, as in rats, cockerels, rams and bulls (Hochereau-de Reviers et al., 1978; de Reviers et al., 1980). Moreover, since Sertoli cells appear to determine the quantity of preleptotene spermatocytes that continue further into meiotic prophase (Huckins, 1978), their population size defines the genetic potential of the gonads for producing spermatozoa. Parameters involved in the genetic control of Sertoli cell numbers presumably are complex. FSH has been implicated as a promoter of Sertoli cell proliferation during development, primarily because of its ability to stimulate divisions of these prepubertal cells both in primary cultures (Griswold et al., 1977) and in vivo (Orth, 1982). The amount of gonadotrophin required for inducing cell divisions in vitro is substantial, and the effect on the mitotic index is minor. This suggests that the observed effect may be mediated through some indirect mechanism or by a contaminating growth factor.

At the onset of testicular development the primordial germ cells arrive from the yolk sac endoderm to populate the gonadal primordia (Bellvé, 1979), presumably by migrating along a predetermined tract in response to an unidentified chemoattractant. During migration and once within the interior of the primordial seminiferous cords, the germ cells continue to proliferate, increasing $\sim 5$ - to 8 -fold in number until late gestation. Both events, migration and proliferation, could involve one or more growth factors, each acting as a chemoattractant and as a mitogen. At this time the cells become arrested in the $G_{1} / G_{0}$ phase of the mitotic cycle and thereafter undergo a prolonged period of growth (Fig. 1). This growth phase lasts until several days after birth, when the cells reinitiate a synchronous wave of DNA synthesis to generate the first cohort of the spermatogenic series. Simultaneously, the germ cells migrate from the interior of the seminiferous cords to the outer boundary, thereby assuming a closer proximity to the circulating blood (Huckins \& Clermont, 1968). From this time onward the spermatogonia establish a cyclic pattern of renewal and proliferation to provide the required progenitor cells for sustaining the continuum of spermatogenesis (Clermont, 1972).

The precise regulation of spermatogonial divisions, in keeping with the repeating cycle of the seminiferous epithelium, suggests that local factors exist to control the continual entry of stem cells into the mitotic cycle and their subsequent differentiation toward meiosis (Bellvé, 1979). Likewise, among cells of a given syncytium, the final phase of bulk, semi-conservative DNA synthesis of preleptotene spermatocytes occurs in an apparently synchronous pattern, as do the two subsequent proliferative, meiotic reduction divisions. These highly co-ordinated events must involve complex control mechanisms, which presumably involve a cascade of growth factors, each acting at a specific point in the pathway to promote further divisions.

At this time, no direct evidence exists to demonstrate the presence of positive promotors of spermatogonial and/or spermatocyte proliferation. However, the new and extensive proliferation of undifferentiated stem cells that occurs in response to the depletion of spermatogenic cells, following X-irradiation (Dym \& Clermont, 1970), hypophysectomy (Huckins \& Cunningham, 1975), radiation with cobalt-60 (Erickson, 1978) and cytotoxic drug administration (Kerr et al., 1987), is consistent with the action of specific growth factors. A few other reports suggest the presence of an inhibitor of spermatogonial proliferation, a factor appearing to have a preferential effect on the division of type A spermatogonia (Irons \& Clermont, 1979). Depletion of such a factor could lead to a new wave of spermatogonial divisions. Alternatively, this 'chalone-like' activity 


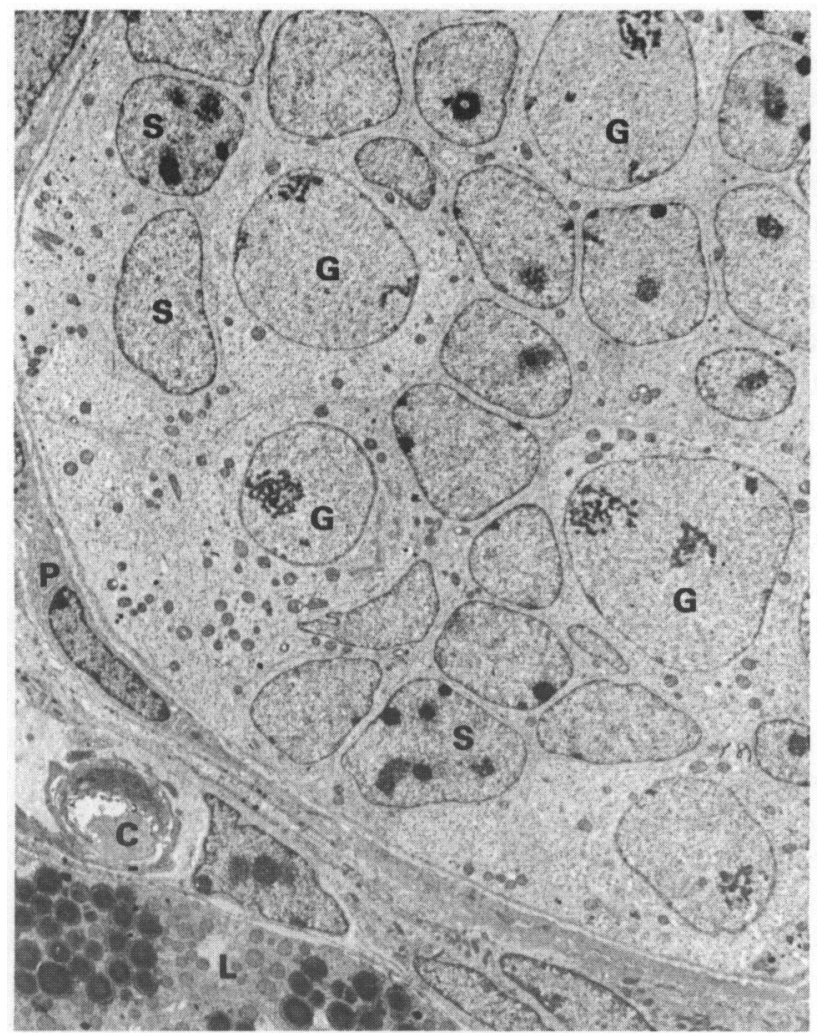

Fig. 1. Electron micrograph of a 7-day-old mouse testis, depicting a segment of seminiferous cord and an adjacent region of interstitium. At this early stage of post-natal development (Days 4-7), a major transition occurs in the organization of the seminiferous epithelium. Primitive type A spermatogonia, after reinitiating DNA synthesis, move to the periphery of seminiferous cords, and undergo a sequence of mitotic divisions and differentiation. Sertoli cells begin forming tight junctions that will become patent by Days 15-18 and thereby divide the epithelium into peripheral and central compartments (Bellvé, 1979). The populations of Leydig and peritubular cells expand in numbers, and express an increasing complexity of differentiated functions. These events herald the onset of spermatogenesis and development of the seminiferous tubules, and presumably require autocrine and paracine interactions of multiple local and serum-derived growth factors. S, Sertoli cells; G, spermatogonia; P, peritubular cell; L, Leydig cell; C, capillary. $\times 2250$.

could be due to one or more growth factors that are inhibitory when present locally at high concentrations. This purported chalone has not been characterized at the present time.

After the gonads first form, the primitive seminiferous cords are enveloped by fibroblast-like myoid cells, precursors to the smooth muscle cells that surround the adult seminiferous tubules. Also during this period of development, mesenchyme cells proliferate to yield differentiated interstitial cells, including the steroidogenic Leydig cells. These latter cells multiply during the remainder of gestation and, by contrast to previous evidence, expand continuously in numbers throughout postnatal development, until mid-puberty. Thereafter, Leydig cells usually do not proliferate. In the adult, renewed proliferation of interstitial cells only occurs in response to non-physiological conditions: (a) to local implants of the testosterone agonist, cyproterone acetate, or the cytotoxic drug, WIN-18446 (Aoki \& Fawcett, 1978); (b) to administration of prolonged and supra-physiological levels of exogenous hCG (Aoki \& Massa, 1972; Christensen \& Peacock, 1980; (c) to induction by the elevated abdominal environment after unilateral cryptorchidism (Kerr \& Donachie, 
1986); and (d) to the depletion of interstitial cells by treatment with the cytotoxic drug, ethane-1,2dimethanesulphonate (EDS) (Jackson et al., 1985; Kerr et al., 1987).

Clearly, during a 2-6-week-period following these treatments, Leydig cells do have the ability to proliferate in response to a mitogenic signal. The occurrence of Leydig cell hypertrophy and hyperplasia and interstitial neo-vascularization, occurring just in the vicinity of germ cell depletion and tissue damage (Aoki \& Fawcett, 1978), is indicative of a localized action of trophic factors. These may emanate from nearby seminiferous tubules, or from interstitial macrophages and circulating blood platelets, in 'immunological' and 'wound healing' responses. In the case of hCG stimulation, it is not known whether the general mitogenic response is due to a direct effect of hCG (or LH), to a minor contaminant, or to an indirect effect mediated via a growth factor from another cell type within the testes. Following EDS-induced cytotoxity, the regeneration of 'fetal' Leydig cells has been reported to occur initially from intertubular regions, and then from the immediate vicinity of the seminiferous tubules (Kerr et al,, 1987). This replenishment of Leydig cell numbers could be promoted by steroids being secreted by Sertoli cells, or by a complex array of growth factors stemming from quite disparate sources.

The different temporal patterns of cell growth suggest that gonadal development must be regulated by an array of growth factors. Modulation of proliferation rates for individual cell populations could be achieved by distinct growth factors, by changes in expression of cell surface receptors for the respective mitogens, by alterations of the cell's signal transduction mechanisms, and/or by selection of different intracellular pathways mediating alternative pleiotypic responses. On considering these options, it becomes evident that the control mechanisms will prove to be complicated, as intricate no doubt as the level of ingenuity expressed in devising assays for detecting and characterizing these novel mitogens and their respective surface ligands.

\section{Testicular growth factors}

Growth factors act primarily through local paracrine and autocrine pathways (Sporn \& Todaro, 1980). Therefore, emphasis will be placed primarily on the properties of those growth factors known to exist in the testes, and secondarily on polypeptides shown to have an effect, but which may originate from extra-gonadal sites. In the former category, are the seminiferous growth factor (SGF), basic fibroblast growth factor (bFGF), somatomedin C/insulin-like growth factor (IGF-I), Sertoli cell-secreted growth factor (SCSGF), transforming growth factor $\alpha$ and $\beta$ (TGF $\alpha$, TGF $\beta$ ), interleukin-1 $\alpha$ (IL-1 $\alpha)$ and $\beta$-nerve growth factor ( $\beta N G F)$. These growth factors have been shown to exist in mammalian testes, based on direct biological assays, biochemical characterization and purification, and/or specific immunological and molecular probes. The second category includes those growth factors, such as epidermal growth factor (EGF) and multiple-stimulating activity or insulin-like growth factor II (IGF-II), that appear to reach the gonads via the vascular circulation.

\section{Seminiferous growth factor ( $S G F)$}

SGF was the first growth factor shown to exist in male gonadal tissue (Feig et al., 1980). This polypeptide is a potent, broad-spectrum mitogen that causes competent target cells to progress from $G_{1}$ into $S$ phase, $G_{2}$ and mitosis. Initially, SGF was identified by applying a mitogenic assay, in which confluent, quiescent, BALB/c $3 T 3$ cells were stimulated to incorporate $\left[{ }^{3} \mathrm{H}\right]$ thymidine into DNA and to undergo multiple cell divisions. This line of fibroblasts is known to respond to a variety of growth factors, and therefore its application circumvented the problematic issue of developing an assay for detecting mitogens active specifically against germ cells. Also, in common with fibroblasts, most cell types within the testes originate from mesenchyme during embryonic development. Blood as a potential source of extra-gonadal growth factors was circumvented by perfusing the testes before undertaking the assays. 
Based on this in-vitro assay, mouse testes, and in particular seminiferous tubules, were shown to contain proteins with mitogenic activity (Fig. 2) (Feig et al., 1980). The mitogens expressed halfmaximal specific activities at $\sim 6$-fold higher levels during the immediate postnatal period than at later stages of development. Moreover, Sertoli cells isolated from the seminiferous epithelium at Day 6 of postnatal development expressed the highest specific activities, with only minimal levels being detected in primitive type A spermatogonia and preleptotene spermatocytes (Feig et al., 1980). Other germ cells did not contain detectable activity. The presence of SGF in the seminiferous cords of $\mathrm{W}^{\mathrm{v}} / \mathrm{W}^{\mathrm{v}}$ mutant mice, which lack spermatogenic cells due to a developmental defect in primordial germ cells (Bellvé, 1979), rather than a somatic cell lesion, is consistent with its localization in Sertoli cells. Notably, seminiferous tubules of vitamin A-depleted, adult rats expressed only minimal levels of stimulating activity $(\sim 4 \%)$ for NIH 3 T3 fibroblasts, compared to those from control animals (Unni et al., 1984). Lastly, mitogenic activity for Swiss 3 T3 fibroblasts was detected in rete testis fluid recovered from the ram, although initial characterization of this heat-stable activity indicated an $M_{\mathrm{r}}$ of $\sim 45000$ (Brown et al., 1982).

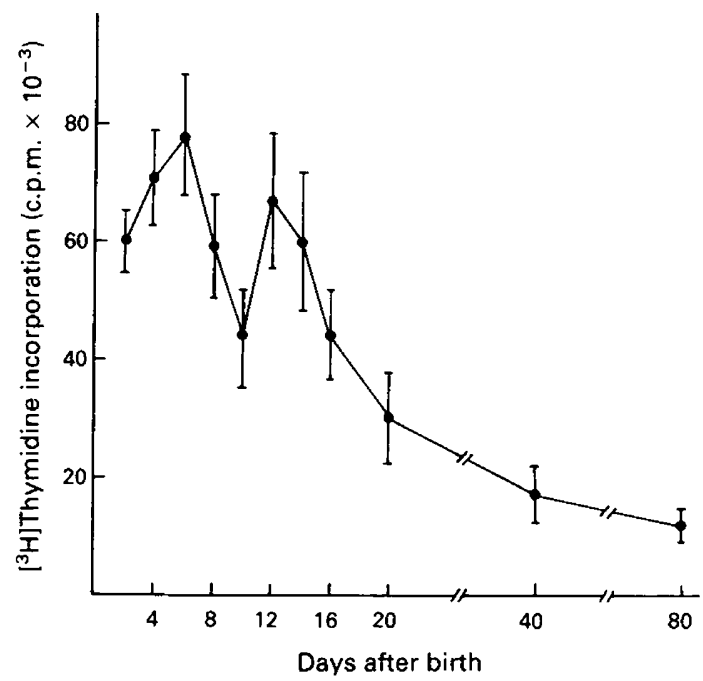

Fig. 2. Quantitation of mitogenic activity in the seminiferous epithelium at different ages of development in the mouse. Seminiferous cords/tubules were recovered from testes at the designated ages, homogenized, and subjected to centrifugation. Supernatant proteins were added, at different concentrations, to quiescent cultures of confluent BALB/c $3 T 3$ cells, in the presence of $\left[{ }^{3} \mathrm{H}\right]$ thymidine. Dose-response curves were generated on quantifying the incorporation of $\left[{ }^{3} \mathrm{H}\right]$ thymidine into DNA. The data points each represent the mean $\mathrm{ED}_{50}( \pm$ s.e. $)$ derived from the different dose-response curves. Notably, half-maximal, specific mitogenic activity attains peaks on Days 4-8 and 12-14 after birth, and therafter declines gradually through to adulthood. These data suggest, and as subsequently proven, that the activity is derived principally from Sertoli cells. The two peaks of activity coincide with the transitional period in the development of the seminiferous epithelium and the onset of spermatogenesis (see Fig. 1). (From Feig et al., 1980.)

SGF activity has been detected in the testes of the mouse, rat, guinea-pig, rabbit and human (Feig et al., 1983), and therefore the polypeptide appears to be ubiquitous to mammalian species. Biochemical characterization and purification of SGF was therefore justified. The activity proved to be heat-sensitive and susceptible to proteolytic digestion, but unlike most other known growth factors, it was insensitive to the reductive effect of dithiothreitol (DTT) (Feig et al., 1980). The major component of the activity was generated by a protein of $M_{\mathrm{r}} 15750$ and a $\mathrm{pI}$ of $5 \cdot 2$, when 
assayed in denaturing conditions (Feig et al., 1983). A minor component ( $\sim 15 \%$ of the total activity did not bind during DEAE ion-exchange chromatography and was isoelectric at pI $\geq 8.0$ (Fig. 3). Together, the two observations suggested the existence of a basic growth factor in mouse and calf testes. The latter activity most likely has been purified and, based on partial sequence homology, identified as a truncated form of bovine bFGF (Ueno et al., 1987).

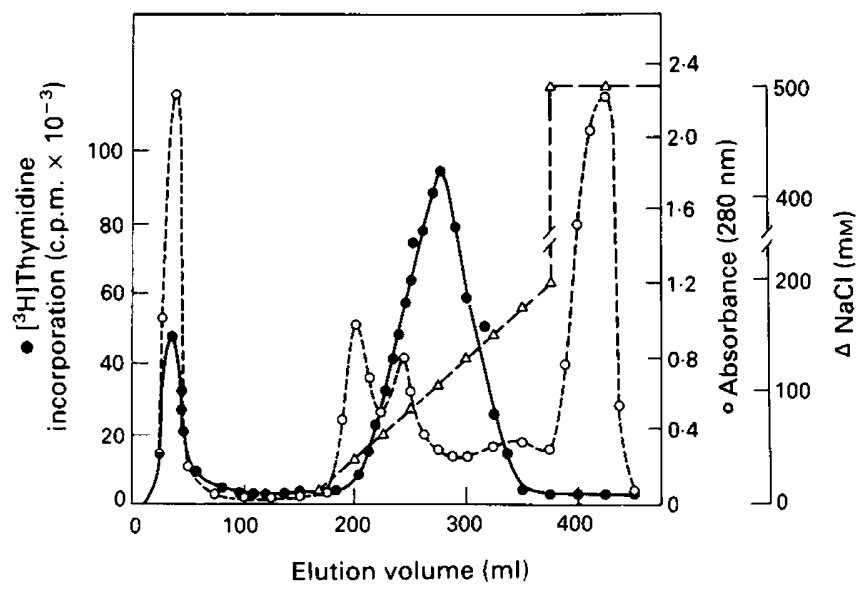

Fig. 3. Ion-exchange chromatography of mitogenic activity from the seminiferous cords of 6- to 8-week-old calves. Growth factor activity was precipitated from a supernatant fraction in the presence of $80 \%$ ammonium sulphate, solubilized, applied to a column of DEAE cellulose $(1.5 \times 10 \mathrm{~cm} ; \mathrm{pH} 6.2)$, and eluted with a $0.0-200 \mathrm{~mm}$ gradient of $\mathrm{NaCl}$. Most of the activity $(\sim 85 \%$ ), SGF, was bound by the column matrix and then later eluted between $\sim 25$ and $165 \mathrm{~mm}-\mathrm{NaCl}$. Some $(\sim 15 \%)$ of the activity was recovered in the flow-through eluant, an observation consistent with the presence of a basic growth factor in prepubertal testes (see text). SGF activity was purified further by a sequence of chromatography on sepharoseconjugated Cibracon dyes, Green A and Orange A, and then heparin, followed by reversephase h.p.l.c. Comparable data were obtained for activity present in mouse testes. (From Feig et al., 1983.)

Calf SGF has been purified $\geqq 80000$-fold by applying $\mathrm{NH}_{4}\left(\mathrm{SO}_{4}\right)_{2}$ precipitation and a sequence of affinity chromatography on different Sepharose-conjugated ligands; the Cibracon dyes, Green A and Orange $A$, and then heparin. These steps were followed by reverse-phase, high-performance liquid chromatography (h.p.l.c.) on an octaphenyl column, developed with a linear gradient of 20$45 \%$ acetonitrile in $1 \%$ trichloroacetic acid. The two dye-ligand affinity columns, both developed with gradients of $150-500 \mathrm{mM}-\mathrm{KCl}$, proved to be efficient methods for resolving SGF activity. Orange A-derived mitogenic activity, when applied to the heparin-affinity column, eluted at $\sim 1.2 \mathrm{M}$-salt after applying a linear gradient of $0.5-2.5 \mathrm{M}-\mathrm{NaCl}$ (Fig. 4). After fractionation by reverse-phase h.p.l.c., the activity was recovered in two peaks that each resolved into a single polypeptide species when subjected to SDS-PAGE (Fig. 4). The two proteins had $M_{\mathrm{r}}$ values of $\sim 16500$ and $\sim 15250$.

Studies on the biological properties of SGF have shown the protein to be mitogenic for cells derived from mouse testes. Purified SGF induced 6-day-old mouse Sertoli cells in primary culture to proliferate extensively, even when in the presence of only minimal levels of serum (Bellvé \& Feig, 1984). This effect has been studied further by utilizing $\mathrm{TM}_{4}$ cells, a transformed line of Sertoli cells derived from 18-day-old mouse testes (Mather, 1980). These cells have the distinct advantage of being able to grow in defined medium ( 1 vol. DME: 1 vol. Hams F12) (DME/F $12^{\circ}$ ), when supplemented with EGF, insulin and transferrin (DME/F12*) (Mather, 1980). It therefore proved 


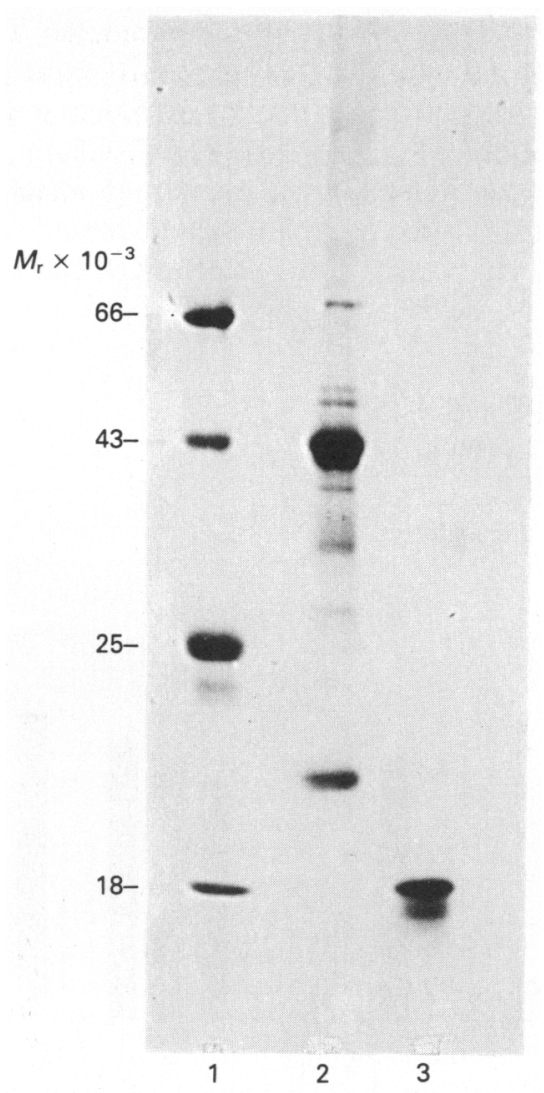

Fig. 4. Resolution of SGF activity by SDS-PAGE. After purification by a sequence of ion exchange and affinity chromatography, as outlined in the legend to Fig. 3, heparin affinitypurified proteins were resolved by $14 \%$ linear SDS-PAGE. Two major peptide bands, $M_{\mathrm{r}}$ values of 16500 and 15250 , were present. Both peptides express mitogenic activity for BALB/c $3 \mathrm{~T} 3$ and $\mathrm{TM}_{4}$ cells. Lane 1, standard proteins; Lane 2, Orange A-purified proteins; Lane 3, heparin-purified proteins. (From Bellve et al., 1989.)

possible to utilize $\mathrm{TM}_{4}$ Sertoli cells to assess the biological properties of SGF, in the presence and absence of different combinations of these growth promoters. EGF, insulin and transferrin, when added alone or in two-way combinations, were not mitogenic for $\mathrm{TM}_{4}$ cells (Fig. 5). Only the threeway combination of EGF, insulin and transferrin enabled the cells to proliferate at $\sim 70 \%$ of the rate attained with $5 \%$ serum, as reported previously (Mather \& Phillips, 1984). By contrast, SGF added alone, at 1 unit $/ \mathrm{ml}$ (50\% maximal stimulation for $3 \mathrm{~T} 3$ cells), induced $\mathrm{TM}_{4}$ Sertoli cells to proliferate at a rate exceeding that obtained with DME/F12*. Likewise, when SGF was added at 2 units $/ \mathrm{ml}$, the $\mathrm{TM}_{4}$ cells proliferated at a rate equivalent to $5 \%$ serum addition and often exceeded this level by $\leqslant 15 \%$. No synergistic effects were observed; each combination of SGF with EGF, insulin and/or transferrin gave proliferation rates equivalent to those with SGF alone (Fig. 5). In these culture conditions, therefore, SGF was sufficient to enable $\mathrm{TM}_{4}$ Sertoli cells to achieve maximal rates of proliferation. Only $1 \mu \mathrm{M}$-retinoic acid, and not retinol or retinyl aldehyde, depressed the mitogenic response to SGF (unpublished). Polypeptide hormones and other growth factors having functions in male reproductive biology were tested to determine whether any have mitogenic activity. SGF, in the complete absence of serum, had major effects on the proliferation rates of 
both $\mathrm{TM}_{3}$ and $\mathrm{TM}_{4}$ cells (Fig. 6). By contrast, aFGF induced only $\mathrm{TM}_{3}$ Leydig cells to proliferate, and bFGF had no real effect on either cell line. Moreover, SGF, aFGF and bFGF caused the two lines to synthesize and secrete very different patterns of $\left[{ }^{35} \mathrm{~S}\right]$ methionine-labelled proteins, as determined by IEF/SDS-PAGE analyses (W. Zheng \& A. R. Bellvé, unpublished). Other trophic factors tested, FSH, LH and prolactin had minimal or no measurable effects on $\mathrm{TM}_{4}$ cell proliferation (S. J. Braunhut, R. A. Rufo, B. J. Ernisee \& A. R. Bellvé, unpublished). Finally, four polyclonal antibodies directed against known peptide domains or aFGF and bFGF did not bind to SGF on immunoblots (W. Zheng \& A. R. Bellvé, unpublished).

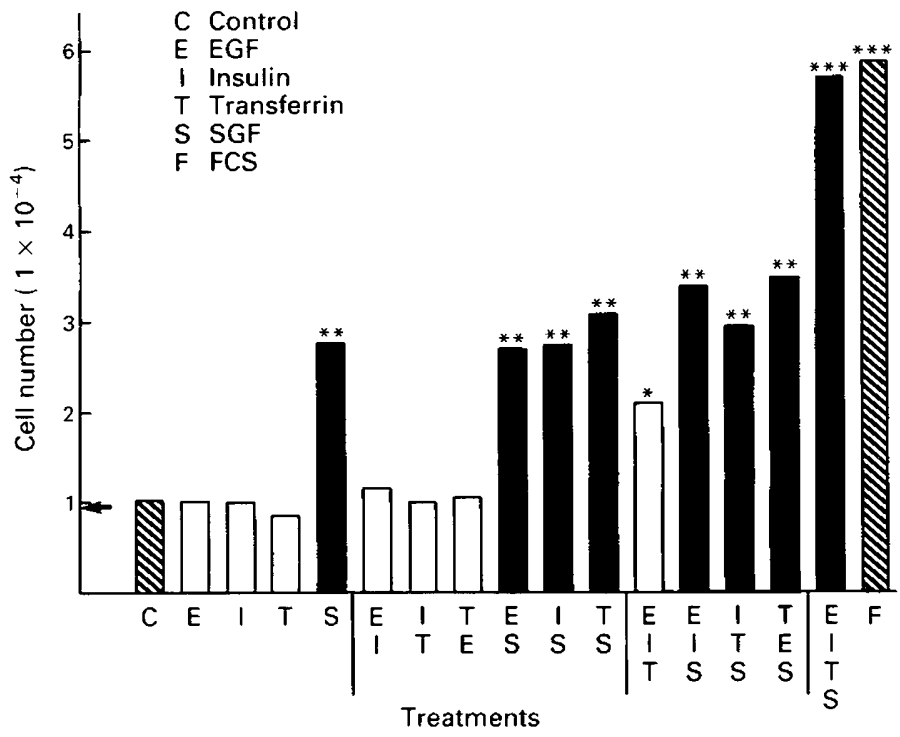

Fig. 5. Effects of SGF, EGF, insulin and transferrin on the proliferation of $\mathrm{TM}_{4}$ Sertoli cells in serum-free, DME/F12 medium (DME/F12 $)$. The cells were cultured in the presence of SGF (l unit/ml) and maximal levels of EGF, insulin and transferrin, each singly and in all two-, three- and four-way combinations. After a further $48 \mathrm{~h}$ of culture, cell numbers were quantified. SGF at these half-maximal levels, was sufficient to induce growth of $\mathrm{TM}_{4}$ cells, whether added alone or in combination with the other trophic factors. Addition of EGF, insulin and transferrin, singly or in any two-way combination were not mitogenic for these cells. The threeway combination of EGF, insulin and transferrin promoted growth of $\mathrm{TM}_{4}$ cells, as reported previously (Mather, 1980), but was not as effective as maximal stimulation with SGF (2 units). No additive or synergistic effect of SGF with the other growth promoters was observed. In the different treatments SGF was either present (black bars) or absent (white bars). DME/F12 ${ }^{\circ}$ negative control and DME/F12* positive control are indicated by the hatched bars. ${ }^{*} P \leqq 0.05$; ${ }^{* *} P \leqq 0 \cdot 01 ;{ }^{* * *} P<0 \cdot 001$. (From Braunhut et al., 1989.)

In conclusion, SGF, aFGF and bFGF each caused distinct pleiotypic responses in the testisderived $\mathrm{TM}_{3}$ and $\mathrm{TM}_{4}$ cell lines, and SGF lacks at least four peptide epitopes known to occur within aFGF or bFGF. It will be important, therefore, to resolve whether these 3 related growth factors act through distinct surface receptors, alternative transmembrane transduction mechanisms, and/or different intracellular pathways. It is concluded, on the basis of this evidence, that SGF is a novel testicular growth factor, and can be expected to have unique functions in male reproduction. 


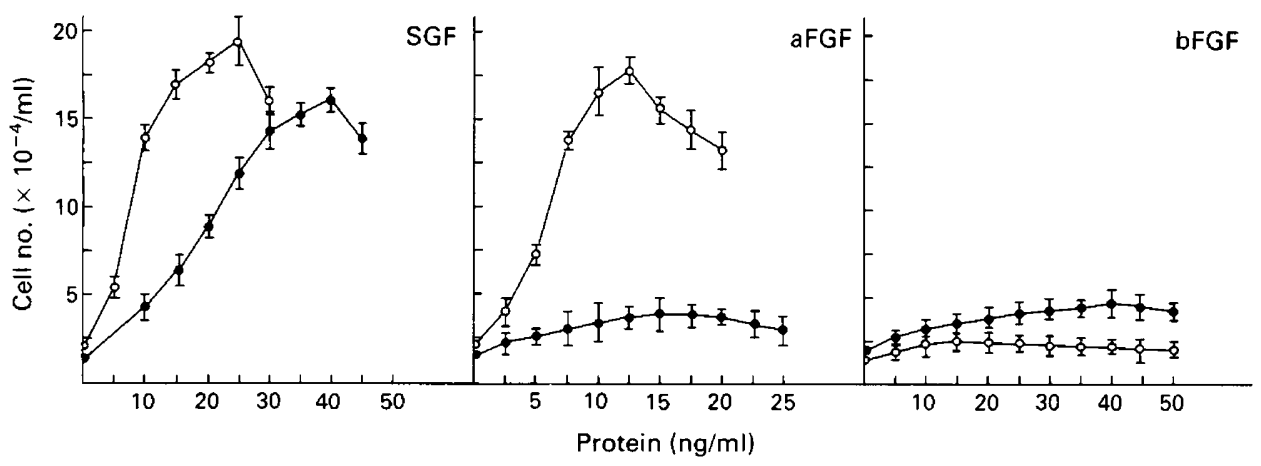

Fig. 6. Effect of SGF, aFGF and bFGF on the proliferation of $\mathrm{TM}_{3}$ and $\mathrm{TM}_{4}$ cells in the serumfree, $\mathrm{DME} / \mathrm{F} 12^{\circ}$ medium. Both lines were seeded at $25 \times 10^{3}$ cells $/ \mathrm{ml}$ in the presence of DME/ F12* for $48 \mathrm{~h}$. At the end of this equilibration period, the spent medium was removed and the cells were washed twice with DME/F12 ${ }^{\circ}$. Then, after $24 \mathrm{~h}$ in the presence of DME/F $12^{\circ}, 1$ of the 3 growth factors was added, at the concentrations indicated. After another $48 \mathrm{~h}$ of culture, cell numbers were quantified. Notably, SGF is able to induce both $\mathbf{T M}_{3}$ and $\mathrm{TM}_{4}$ cells to proliferate, whereas aFGF has a marked effect only on $\mathrm{TM}_{3}$ cells, and bFGF is not mitogenic for either cell line. $\mathrm{O}, \mathrm{TM}_{3}$ Leydig cells; $-\mathrm{TM}_{4}$ Sertoli cells. (From W. Zheng \& A. R. Bellvé, unpublished.)

\section{Basic fibroblast growth factor ( $b F G F$ )}

Basic FGF has been purified from bovine testes (Table 1) (Ueno et al., 1987). The protein was identified by its ability to induce proliferation of bovine aortic arch endothelial cells, combined with a radioimmunoassay specific for a known decapeptide sequence of bFGF (aa: $\left.\mathrm{Tyr}_{10} ; 1-10\right)$. Purification of the testicular bFGF was accomplished by applying a sequence of ammonium sulphate precipitation, ion-exchange chromatography, heparin-affinity chromatography and 3 successive steps of reverse-phase chromatography. The purified protein, when subjected to gas phase sequencing, proved to have the same primary structure, for the first 9 amino acids at the amino-terminus, as the truncated form of bFGF (aa: 16-146). This sequence is present in bFGF isolated from the pituitary (Esch et al., 1985), brain (Gospodarowicz et al., 1984; Böhlen et al., 1985; Burgess et al., 1985; Gimenez-Gallego et al., 1985), retina (Baird et al., 1985), placenta (Gospodarowicz et al., 1985 ) and adrenal gland (Gospodarowicz et al., 1986). Truncated bFGF has full mitogenic activity and is able to promote proliferation of fibroblasts and endothelial cells. The protein therefore can be expected to have important functions in mesenchyme cell growth and neovascularization during gonadal development. This aspect alone warrants considerable efforts to discern the role of bFGF in the onset and maintenance of mammalian spermatogenesis.

This growth factor, when purified from bovine brain, has been shown to be an effective mitogen for Sertoli cells recovered from 3-4-week-old pigs (Jaillard et al., 1987). In fact, bFGF was an order of magnitude more potent as a mitogen on these cells than was IGF-I, and 2-3 orders more effective than insulin. The simultaneous addition of bFGF and IGF-I led to a synergistic response in $\left[{ }^{3} \mathrm{H}\right]$ thymidine incorporation by Sertoli cells, whereas the effect of insulin was less than additive. In the presence of bFGF and insulin, the addition of pig FSH had a marked inhibitory effect on $\left[{ }^{3} \mathrm{H}\right]$ thymidine incorporation (Jaillard et al., 1987). If the same phenomenon occurs in vivo then the developmental proliferation of Sertoli cells occurring in response to SGF and bFGF may be inhibited gradually during the prepubertal period by the increasing concentrations of serum FSH.

The effect of bFGF extended beyond stimulating DNA synthesis. In the presence of insulin, bFGF increased binding of ${ }^{125}$ I-labelled human FSH, cAMP production and plasminogen activator activity of pig Sertoli cells (Jaillard et al., 1987). Comparable effects of bFGF were observed for 


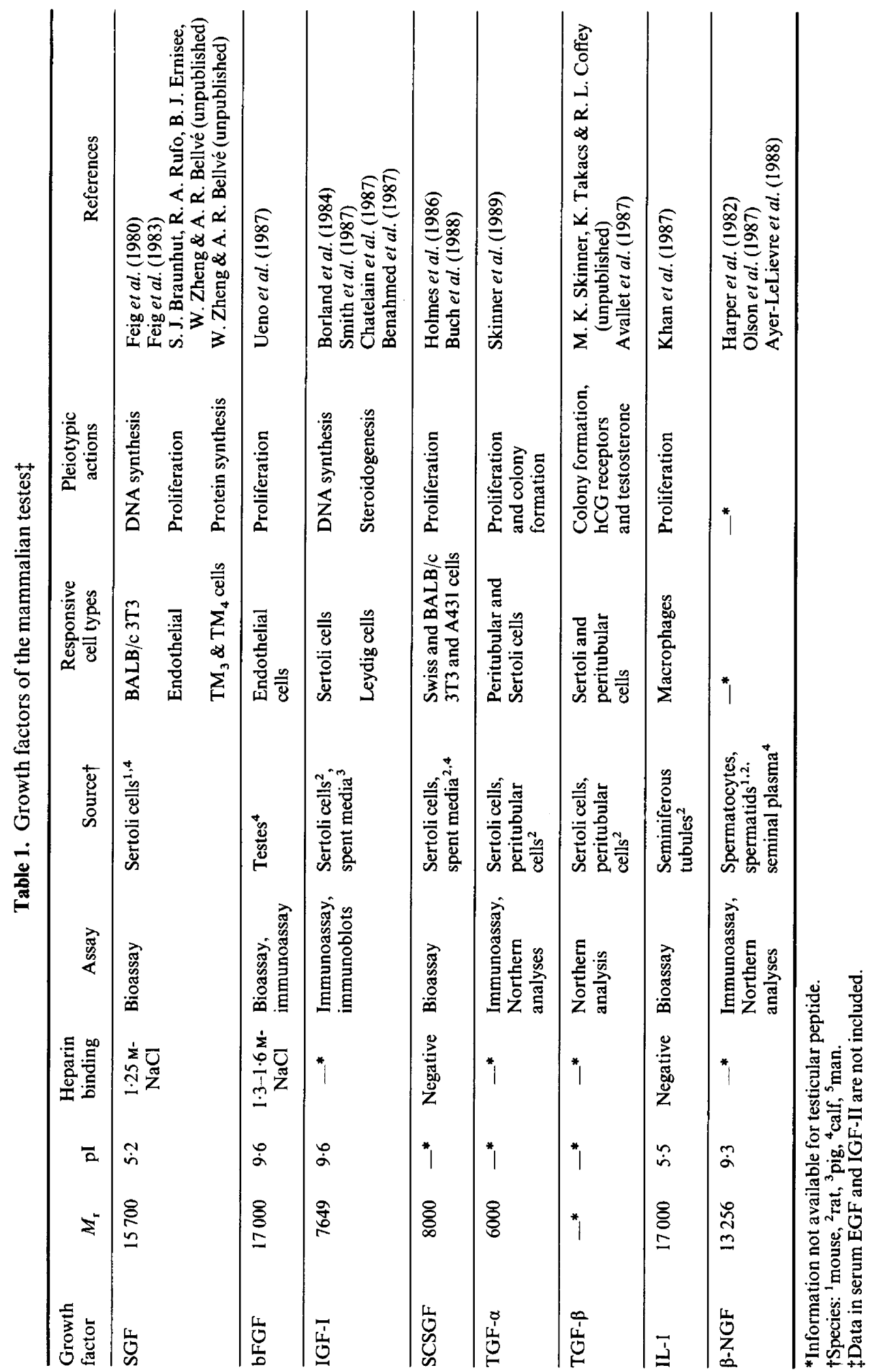


15-day-old and 29-day-old rat Sertoli cells grown in the presence of transferrin. However, one note of caution needs to be mentioned. These Sertoli cell cultures were contaminated to $\sim 3 \%$ with myoid cells. The possibility therefore exists that some or all of the observed actions of bFGF were incurred via these peritubular cells. However, even if the trophic effects were mediated through an indirect paracrine pathway, it is evident that bFGF will prove to be an important regulator of Sertoli cell functions.

\section{Insulin-like growth factor I (IGF-I)}

IGF-I, otherwise referred to as non-suppressible insulin-like activity or somatomedin C, has been reported to exist in rat testes (Hall et al., 1983; D'Ercole et al., 1984; Handelsman et al., 1985). Evidence to support the existence of this 'competence factor' in mammalian testes is substantial. First, an antibody specific for serum IGF-I gave parallel, dose-response curves when reacted with acid-extracted, testicular proteins (Handelsman et al., 1985; Benahmed et al., 1987). Second, the immunoreactive material co-eluted on isocratic chromatography (Handelsman et al., 1985; Benahmed et al., 1987) and co-migrated on SDS-PAGE immunoblots (Smith et al., 1987), along with authentic IGF-I. Both methods led to an estimated $M_{\mathrm{r}}$ of 8000 , which is comparable to the known mass of IGF-I (Table 1). Third, the testicular material was isoelectric at pI 9.6, and therefore identical to that of rat serum IGF-I (Smith et al., 1987). Fourth, IGF-I mRNA transcripts have been detected among testis poly[A $\left.{ }^{+}\right]$RNA, by Northern analyses (Casella et al., 1987), although reportedly at considerably lower levels of abundance than occur in liver (Murphy et al., 1987). Fifth, a binding protein of $M_{\mathrm{r}} \sim 25000$ for IGF-I has been detected in medium collected from Sertoli cell cultures (Smith et al., 1987).

IGF-I occurs in rat testes at a concentration of 1.88 units/g tissue, approximately equal to that present in liver, lung and kidney, the major organs producing this polypeptide (D'Ercole et al., 1984). However, due to their comparatively small mass, the testes probably do not contribute significantly to the considerable amounts of IGF-I known to exist in serum ( $28.5 \mathrm{units} / \mathrm{ml})$. Testicular IGF-I, as with most other organs in the rat, is subject to control by GH from the pituitary. Thus, a few hours after administering sheep GH to hypophysectomized rats, the deplenished levels of IGF-I immunoreactivity are increased 3-4-fold, in a dose-dependent pattern (D'Ercole et al., 1984). This response occurred before a 30 -fold increase in serum levels, suggesting that it reflected testicular production of IGF-I rather than retention from the pool of growth factor circulating in serum.

Existing evidence demonstrates that several types of cell in the testes are responsive to IGF-I, including Leydig and Sertoli cells. For Leydig cells the data are contradictory. Initially, it was reported that steroidogenesis was not influenced by the addition of IGF-I to a $3 \mathrm{~h}$ culture of Leydig cells (Handelsman et al., 1985). By contrast, in subsequent studies, it was found that IGF-I stimulated hCG-induced testosterone production by both rat (De Mellow et al., 1987) and pig (Benahmed et al., 1987) Leydig cells. Likewise, when the peptide was added to cultures $24 \mathrm{~h}$ before gonadotrophin, it again enhanced the level of both basal and hCG-induced, testosterone production by purified, rat Leydig cells (Lin et al., 1986). The response of hCG-induced Leydig cells to IGF-I occurred in a dose-dependent manner, in the range of 10-100 ng peptide $/ \mathrm{ml}$. Similar results were obtained with a crude preparation of $\mathrm{LH}$-induced, rat interstitial cells, except that no effect was observed on the basal levels of steroidogenesis (Kasson \& Hsueh, 1987). The effect on steroidogenesis presumably reflected the maintenance of a near 'normal' number of hCG receptors (Bernier et al., 1986).

The effect of IGF-I on hCG number and steroidogenesis was most probably mediated through the type I receptor. Both IGF-II and insulin were required at 10 -fold or more greater concentrations (Bernier et al., 1986; Kasson \& Hsueh, 1987). It is not clear, however, whether the effects were specific for hCG-induced testosterone production, or simply reflected a general maintenance 
of the 'normal' levels of cell metabolism in the limited conditions of culture. In this regard, IGF-I prevented the decline in hCG receptor number that usually occurs during the primary culture of Leydig cells (Bernier et al., 1986). Comparable studies in vivo to resolve such issues would be difficult and thwart with problems of interpretation.

Sertoli cells also appear to respond to IGF-I. Those cells isolated from 13-day-old rats expressed an increase in the incorporation of $\left[{ }^{3} \mathrm{H}\right]$ thymidine in response to IGF-I (Borland et al., 1984). In prepubertal animals, therefore, IGF-I may act to induce Sertoli cell DNA synthesis and proliferation, at least until their divisions cease between Days 12 and 15 after birth. It also is likely that IGF-I may be the primary mediator of some of the observed effects of insulin on Sertoli cells, such as the increased production of lactate and synthesis of cellular proteins (Borland et al., 1984; Mita et al., 1985). Lactate production is known to be under the control of FSH (Mita et al., 1982), and is important for germ cell metabolism (Mita \& Hall, 1982). The effects of IGF-I, FSH and insulin have been reported to be identical (Oonk, 1987; Oonk \& Grootegoed, 1988). Both IGF-I and insulin stimulated the rate of sugar uptake and the activities of several glycolytic enzymes in cultured rat Sertoli cells. In the adult, IGF-I could induce Sertoli cells to express a variety of pleiotypic responses, including the secretion of specific proteins involved in autocrine and paracrine functions. Vectorial secretion of IGF-I by Sertoli cells in vivo, into the adluminal or central compartment of the seminiferous epithelium, would offer the possibility that the protein acts to modulate germ cell differentiation. This will be a difficult premise to check, because it is not yet possible to obtain viable cultures of Sertoli cells from adult animals.

Localization of IGF-I to testicular cells has been accomplished by applying immunofluorescence microscopy. Following the in-vitro culture of dispersed testicular cells, IGF-I immunoreactivity occurred primarily in rat Leydig and peritubular cells, at low levels in a small proportion of the Sertoli cells, and minimally in spermatocytes (Tres et al., 1986). Likewise, studies on IGF-I distribution within human testes, in situ, also have localized the growth factor to Sertoli cells, and to a lesser extent in primary spermatocytes and spermatids (Vannelli et al., 1988). In both studies, the identify of IGF-I was not verified by immunoblot analyses, leaving open the possibility that the immunoreactivity may represent non-specific, cross-reacting proteins.

Transcription of the IGF-I gene and production of the peptide has been demonstrated to occur in testes. A cDNA complementary to rat testis IGF-I mRNA has been cloned following screening of a $\lambda$ gt 11 expression library and subjected to nucleotide sequencing (Casella et al., 1987). Significantly, the predicted primary structure of the rat testis IGF-I precursor shares considerable homology with that of human liver IGF-IA. Homologies of $86,86,88$ and $79 \%$ have been found within the $5^{\prime}$-untranslated region, the putative 22 -amino-acid signal peptide, the coding sequence, and the 3 '-untranslated region, respectively (Casella et al., 1987). Of 11 predicted amino-acid substitutions, only 3 exist within the coding sequence. Two potential methionine initiator codons are present in the rat IGF-I cDNA, suggesting possible synthesis of precursor molecules of 153 and 127 amino acids. However, of the multiple methionine initiation sites within the mouse, rat and human IGF-I sequences, only the one at position -22 is conserved between species. This is also the most likely initiator codon, since it is followed immediately by a sequence of 21 hydrophobic amino acids, characteristic of a signal sequence. Whether this is the preferred initiator site for IGF-I gene expression in rat testis must be determined by undertaking in-vitro translation studies.

The cDNA probe for IGF-I mRNA hybridized with transcripts of $7 \cdot 5,4 \cdot 7,1 \cdot 7$ and $1 \cdot 2-0 \cdot 9 \mathrm{~kb}$, among the poly[ $\left.\mathrm{A}^{+}\right]$RNAs prepared from rat testes and liver (Casella et al., 1987). The larger $7 \cdot 5$ and $4.7 \mathrm{~kb}$ sequences were not recognized by a second cDNA probe, indicating perhaps that neither may be translated. Assuming the 1.7 and $1.2-0.9 \mathrm{~kb}$ poly[ $\left.\mathrm{A}^{+}\right]$RNAs are translated, these data provide direct evidence for the synthesis of IGF-I in testes. Notably, the predicted amino sequence of rat testis IGF-I contains 3 amino acid substitutions from the human liver peptide. Yet the two characterized IGF-Is differ substantially in pI $(9.6$ and 8.5$)$, a difference that apparently cannot be accounted for by the chemical nature of the 3 substitutions. This apparent discrepancy could be due 
to the existence of two rat IGF-I precursors, one analogous to the second peptide shown to occur in other species. Alternatively, it may reflect a difference in the tertiary conformation, and therefore the net surface charge of the two proteins.

Target cells for IGF-I, whether the latter originates from serum or testicular sources, can be identified by localizing, quantifying and characterizing cell surface receptors. IGF type I receptors are present on Sertoli cells (Borland et al., 1984; Vannelli et al., 1988) and Leydig cells (Handelsman et al., 1985). Cross-linking studies with a Sertoli cell membrane preparation and ${ }^{125}$ I-labelled IGFI have demonstrated the existence of the native receptor of $M_{\mathrm{r}} 350000$ (Borland et al., 1984). In reducing and denaturing conditions, this structure gave the expected $M_{\mathrm{r}} 125000(\alpha)$ and $90000(\beta)$ subunits of the native $(\alpha \beta)_{2}$ receptor. On Sertoli and Leydig cells, the receptors were present in numbers and exhibited binding affinities $\left(K_{\mathrm{a}} 2 \times 10^{9} \mathrm{M}^{-1}\right)$ characteristic of those present in somatic tissues (Handelsman et al., 1985; Lin et al., 1986). Moreover, these receptors bound insulin when the latter was present at supra-physiological, micromolar concentrations. It seems likely that many of the reported effects of insulin on testicular cells probably are mediated in vivo through the type I IGF receptor.

Leydig cells are exposed continuously to serum IGF-I $(5-10 \mathrm{nmol})$, at $\leqslant 14$-fold greater concentrations than have been shown to occur within neighbouring peritubular, germ and Sertoli cells. Consequently, effects on Leydig cell activity probably would depend on changes in the local vascular permeability to serum IGF-I, on the rate of production and secretion of endogenous IGF-I into the extra-vascular space, and on the expression of Leydig cell surface receptors for this growth factor. One exception may be occurring in vivo. Only a subpopulation of Leydig cells appeared to express immunoreactivity to an antibody against the type I IGF receptor (Vannelli et al., 1988). This suggests that Leydig cells may be modulating expression of the receptor and perhaps a discrete population of peritubular cells may be secreting IGF-I locally into the perivascular space and thereby exerting a local paracrine control of Leydig cell function. At this time, however, it seems more logical to conclude that serum IGF-I would have an overwhelming influence on Leydig cell activity, and that local modulation would occur through changes in receptor expression.

A reasonable hypothesis is that IGF-I is synthesized and secreted by Sertoli cells and acts, through a paracrine mechanism, on spermatocytes and spermatids. The demonstrated accumulation of immunoassayable IGF-I in the medium of cultured Sertoli cells is in keeping with this hypothesis (Hall et al., 1983; Tres et al., 1986; Smith et al., 1987; Chatelain et al., 1987). The level of IGF-I production increased when Sertoli cells were cultured in the presence of GH, FSH (Tres $e t$ al., 1986), EGF or FGF (Chatelain et al., 1987). The apparent secretion of this growth factor from the testes is evident also by the detection of IGF-I immunoreactivity in seminal plasma of fertile patients, but not in samples taken from subjects experiencing lesions of the seminiferous tubules (Baxter et al., 1984; Barni et al., 1987). Together, these data are consistent with the premise that IGF-I is synthesized and secreted by Sertoli cells in vivo. However, the notion still needs to be validated by Northern analyses, in-situ hybridization, in-vitro translation and immunoblot analyses, to quantify and localize the encoding mRNAs and identify the protein.

In this context, the type I IGF receptor has been localized, to secondary spermatocytes and spermatids in the rat, by immunofluorescence with a specific antibody (Vannelli et al., 1988). The identity of this immunoreactivity in germ cells has yet to be verified by IGF-I binding studies and immunoblot analyses, but the observation is consistent with the previously reported localization of IGF-I within pachytene spermatocytes (Tres et al., 1986). At present the function of the IGF-I receptor in germ cell metabolism remains unknown. It is possible that the growth factor may induce spermatocytes to enter the two meiotic divisions, or stimulate the haploid spermatids to express as yet unknown pleiotypic responses crucial for their continued differentiation. Finally, since IGF-I could be secreted into the lumen of the seminiferous tubules, the peptide may interact with specific receptors and thereby exert effects on epithelial cells lining the epididymides and vasa deferentia. 


\section{Insulin-like growth factor II (IGF-II)}

IGF-II, and the homologous rat polypeptide, multiple-stimulating activity, are members of the somatomedin growth factor family. These proteins have a variety of mitogenic, anabolic and differentiative effects on various tissues (Baxter, 1986). However, based on Northern analyses the gene for IGF-II is not transcribed at detectable levels in rat testes (Murphy et al., 1987). Presumably then, physiological processes responsive to IGF-II would depend on the interaction of the serum protein with endogenous cellular receptors. IGF-II binds to a type II membrane receptor, which exists as a monomer of $M_{\mathrm{r}} 230000 / 240000$ (Massague \& Czech, 1982). This receptor has only a low affinity for IGF-I (3-10\%), and it does not bind insulin. The function of the type-II receptor, in non-gonadal tissues, is not resolved. Unlike the $(\alpha \beta)_{2}$ type-I IGF receptor, the monomeric, type-II IGF membrane receptor has only a short peptide domain at the cytoplasmic surface and lacks detectable tyrosine kinase activity (Morgan et al., 1987). The type II IGF receptor, based on the sequence of the cDNA complementary to the encoding mRNA, appears to be homologous to the $M_{\mathrm{r}} 230000$ cation-independent mannose 6-phosphate receptor (Morgan et al., 1987), a protein implicated in the targetting of lysosomal enzymes to lysosomes (Lobel et al., 1987). Apparently, the IGF-II-mannose 6-phosphate receptor is a multifunctional binding protein, that even contains a sequence homologous to a known fibronectin-binding domain.

In gonadal tissue, binding and cross-linking studies with ${ }^{125} \mathrm{I}$-labelled IGF-II have demonstrated type-II receptors of $M_{\mathrm{r}} 230000$ present in membranes prepared from brain, kidney and testes, and another family of $M_{\mathrm{r}} 240000$ in those of heart, fat and adrenal gland (Taylor et al., 1987). These authors noted that testicular membranes had the highest concentration of receptors/ $\mu \mathrm{g}$ protein, by comparison to other tissues. The type-II IGF receptors have been shown to occur in Sertoli cell membrane preparations (Borland et al., 1984). It needs to be determined whether these receptors are localized preferentially to the basal or apical surfaces of Sertoli cells in vivo, and actually mediate an IGF-II response. It is known that Sertoli cells from prepubertal rats, when stimulated with nanomolar concentrations or IGF-II, expressed increased levels of transferrin synthesis (Skinner \& Griswold, 1983), lactate production and protein synthesis (Borland et al., 1984). In each case, though, it was not established whether IGF-II was acting through the type-I or -II receptor.

The mannose 6-phosphate receptors of $M_{\mathrm{r}} 230000$ and 46000 occur on germ cells (O'Brien et al., 1988): pachytene spermatocytes and spermatids (steps 1-8) accumulate ${ }^{125}$ I-labelled lysosomal enzymes containing mannose 6-phosphate. Also, when the mannose 6-phosphate receptors were affinity-purified from $\left[{ }^{35} \mathrm{~S}\right]$ methionine-labelled germ cells and examined by SDS-PAGE autoradiography, both cell types synthesized proteins that comigrated with the $M_{\mathrm{r}} 215000$ cation-independent and $M_{\mathrm{r}} 46000$ cation-dependent mannose 6-phosphate receptors (O'Brien et al., 1988). These observations demonstrate that differentiating germ cells are capable of mannose 6-phosphate receptor-mediated endocytosis and lysosomal enzyme processing. It remains to be determined whether the germ cell IGF-II-mannose 6-phosphate receptors are accessible to serum IGF-II, or whether both act to transport mannose 6-phosphate-containing, lysosomal enzymes being secreted by Sertoli cells into the central compartment of the seminiferous epithelium. This latter interpretation focusses attention on the possible role of the IGF-II-mannose 6-phosphate receptors in the assembly of the acrosome during spermiogenesis.

\section{Epidermal growth factor (EGF)}

EGF is a small polypeptide $\left(M_{\mathrm{r}} 6045\right)$ that exists as a dimer in association with a larger binding protein (Table 1). In mice, the polypeptide is synthesized and released primarily by the submaxillary salivary glands, and, along with NGF, is under the sexually dimorphic control of testosterone. It occurs at lesser concentrations in other tissues, including brain, thyroid, mammary gland, pancreas, Brunner's glands of the duodenum, jejunum and kidney (Kasselberg et al., 1985). In the 
mouse, EGF is present in the vascular system at concentrations of $5 \mathrm{ng}$ peptide/ml. At these physiological levels serum EGF presumably is sufficient to meet the requirements of EGF-dependent processes occurring in the testes, particularly since the gene encoding EGF does not seem to be transcribed in male gonads (Skinner et al., 1989).

The importance of the submaxillary salivary glands to male reproduction is apparent from the effect of sialoadenectomy and EGF replacement therapy. In adult mice, at 4 weeks after sialoadenectomy the numbers of spermatozoa present in the epididymides were reduced to $45 \%$ of control values (Tsutsumi et al., 1986). This substantial loss occurred even though serum FSH and testosterone concentrations apparently were sustained at normal levels. Surprisingly, in these studies, the concentration of serum LH was not reported, even though EGF is known to be a major factor in regulating the number of hCG-receptors on Leydig cells (Welsh \& Hsueh, 1982). The aspermatogenesis resulting from EGF withdrawal was associated with an accumulation of primary spermatocytes, as if the 'arrest' had occurred at some point during meiotic prophase. Finally, daily administration of EGF, but not of NGF, to mice for 4 weeks after sialoadenectomy maintained normal numbers of epididymal spermatozoa (Tsutsumi et al., 1986). The aspermatogenic and restorative effects therefore appeared to be specific to EGF.

These findings are interesting and raise many questions. It is not apparent how EGF from the submaxillary salivary glands reaches the bloodstream, unless it is reabsorbed intact through the intestinal epithelium. Also, it is difficult to define whether EGF acts via its own receptors or those for TGF- $\alpha$. Perhaps resolution of these and related problems depends on the expression and accessibility of the EGF/TGF- $\alpha$ receptors on the different cell populations within the interstitium and seminiferous epithelium. In the latter case, the existence of the Sertoli cell junctions could represent a physiological barrier to their movement and action, depending on the origin of the two growth factors.

EGF has distinct effects on testicular cells. This growth factor has been shown to cause a marked reducton $(\leqslant 97 \%)$ in the number of hCG receptors on MA-10 cells, a clonal line derived from a Leydig cell tumour (Ascoli, 1981), and on Leydig cells in primary culture (Welsh \& Hsueh, 1982). In addition, EGF also inhibited hCG-stimulated production of testosterone, apparently by decreasing the activities of $17 \alpha$-hydroxylase and 17,20-lyase (Welsh \& Hsueh, 1982). It is also possible that EGF may act directly on peritubular and Sertoli cells, as indicated by in-vitro studies (Mather \& Phillips, 1984) but it is difficult to be certain whether any in-vivo effects are mediated via TGF- $\alpha$ through an EGF/TGF- $\alpha$ receptor, as discussed previously. Similarly, evidence for the presence of EGF-like activities in human seminal plasma (Elson et al., 1984) simply may reflect the production of TGF- $\alpha$, a growth factor known to be expressed in the testes and epididymides (Skinner et al., 1989).

\section{Sertoli cell secreted growth factor (SCSGF)}

SCSGF activity has been found in spent culture medium of Sertoli cells from rat (Holmes et al., 1986) and human (Buch et al., 1988). This SCSGF activity is mitogenic for Swiss 3T3 fibroblasts, A431 epithelial cells, DDT 1 MF-2 smooth muscle cells, and R3327H-G8-A cells from the Dunning prostate, R3327H adenocarcinoma. Similar proliferative responses were obtained for cells of endodermal and mesodermal origin. Comparable activity has been shown to exist in conditioned medium from human Sertoli cells, obtained from patients undergoing male-to-female sexual reassignment, and those undergoing therapeutic orchidectomy for metastatic, prostatic adenocarcinoma or for post-pubertal cryptorchidism (Buch et al., 1988).

Production of SCSGF by rat Sertoli cells was reported to be enhanced by the addition of FSH, testosterone and/or insulin to the cultures (Holmes et al., 1986). This study did not report data on the effects of these hormones on R3327H-G8-A cells, when added alone or in different combinations, even though each is known to have trophic properties. Insulin, for instance, at these 
pharmacological concentrations $(5 \mu \mathrm{g} / \mathrm{ml})$ could have had an effect by cross-reacting with the type-I IGF receptor, and testosterone is required anyway for the growth of R3327H-G8-A cells.

Notably, crude SCSGF can inhibit binding of ${ }^{125}$ I-labelled EGF to its receptor on formalinfixed, A431 cells, suggesting that the two activities may be related (Holmes et al., 1986). The experiments were undertaken with Sertoli cell spent medium, and so it is not yet possible to determine whether the SCSGF mitogenic and EGF receptor-competing activities were due to the same protein. It is also unclear whether the activities were heat-sensitive (Holmes et al., 1986) or heatstable (Buch et al., 1988). Partial purification of SCSGF has been undertaken by fractionating filtered, conditioned, Sertoli cell medium, by both isocratic and anion-exchange chromatography on h.p.l.c. Protein with EGF-receptor competing activity was identified eluting from the columns with relative $M_{\mathrm{r}}$ values of 8000 and 2000 (Holmes et al., 1986). The latter peak of activity may represent a proteolytic product (Buch et al., 1988).

The EGF-competing activity did not bind to heparin, indicating that the protein probably is not related to SGF, aFGF or bFGF, which are all members of the heparin-binding family of polypeptide growth factors. One reasonable premise is that SCSGF activity is related to TGF- $\alpha$, a mitogen of $M_{\mathrm{r}} 7500$ that is produced by normal and transformed cells (Deuel, 1987), and in abundance by both peritubular and Sertoli cells (Skinner et al., 1989). In fact, Holmes et al. (1986) previously have drawn analogies between SCSGF and TGF- $\alpha$.

\section{Transforming growth factor-a (TGF-a)}

Sarcoma growth factor, now identified as TGF- $\alpha$, was discovered as a secretory product of virally-transformed fibroblasts (De Larco \& Todaro, 1978), and since then has been shown to be a product of cells of neoplastic (Derynck, 1986) and embryonic (Lee et al., 1985) tissues. This growth factor is produced in a precursor form, as an integral membrane protein, that is processed into a soluble, extracellular protein (Bringman et al., 1987). TGF- $\alpha$ is a unique polypeptide that shares sequence homology with EGF and binds with high affinity to the EGF receptor. It has been suggested, therefore, that TGF- $\alpha$ may represent an embryonic form of EGF. Recently, however, TGF- $\alpha$ expression has been found to occur in normal adult epithelial cells, including bovine pituitary cells (Samsoonder et al., 1986) and human keratinocytes (Coffey et al., 1987). This suggests that TGF- $\alpha$ could be a regulator of growth in normal adult tissues (Deuel, 1987).

A TGF- $\alpha$-like protein has been shown to exist in rat testes (Skinner et al., 1989). Medium recovered from Sertoli cell cultures contains activity that displaces $\leq 90 \%$ of ${ }^{125}$ I-labelled EGF from a receptor-like protein on human fibroblasts, when added at saturating levels of 5-10 mg protein $/ \mathrm{ml}$ at $4^{\circ} \mathrm{C}$. It is possible, as with SCSGF, that loss of receptor-bound ${ }^{125} \mathrm{I}$-labelled EGF may be due to protease activity present in the conditioned medium. This same medium is also mitogenic for MK cells, an EGF-dependent cell line. On both counts then, this material seems comparable to the SCSGF activity previously found in Sertoli cell-conditioned medium.

Expression of TGF $\alpha$ by gonadal cells has been confirmed by a combination of Northern and immunoblot analyses (Skinner et al., 1989) Isolated peritubular and Sertoli cells, but not differentiating germ cells, contain a $4.4 \mathrm{~kb}$ mRNA that hybridized with a cDNA probe complementary to the sequence encoding TGF- $\alpha$, and comigrated with known TGF- $\alpha$ transcripts from SW620, transformed, colon cells. This TGF- $\alpha$ cDNA probe did not recognize EGF transcripts, nor did an EGFspecific cDNA hybridize with poly[ $\left.\mathrm{A}^{+}\right]$mRNA prepared from Sertoli, peritubular or germ cells. Moreover, TGF- $\alpha$ accumulates, as detected by immunoblot analysis, in the medium of Sertoli and peritubular cell cultures. This observation is consistent with an active secretion process, but proof will require anabolic radiolabelling of immunoprecipitable TGF- $\alpha$.

On the basis of this evidence, it can be concluded that the gene for TGF- $\alpha$, rather than that encoding EGF, is expressed by somatic cells within the seminiferous epithelium, and that the 
ensuing transcripts are translated to yield the mature form of the polypeptide. It can only be presumed that the translational product is processed for secretion in the same manner as authentic TGF- $\alpha$. In addition, identity of testicular TGF- $\alpha$ with SCSGF or other activity in Sertoli/peritubular cell-conditioned medium, and with authentic TGF- $\alpha$ still needs to be determined.

Receptors for EGF/TGF- $\alpha$, characterized by using ${ }^{125}$ I-labelled EGF, exist on rat peritubular cells, but not on Sertoli cells, or on differentiating germ cells (Skinner et al., 1989). Scratched analysis revealed the presence of $\sim 12000$ receptors/peritubular cell, with a $K_{\mathrm{D}}$ of $\sim 3 \cdot 3 \times 10^{-10}$. In keeping with these observations, human recombinant TGF- $\alpha$ induced cultured, rat peritubular cells to proliferate and to form large aggregate colonies. Neither proliferation nor colony formation was observed after addition of TGF- $\alpha$ to Sertoli cells in culture. Finally, when Sertoli and peritubular cells were co-cultured in the presence of TGF- $\alpha$ mixed cell aggregates were formed.

In summary, transcription of the TGF- $\alpha$ gene occurs in cultured peritubular and Sertoli cells, and TGF- $\alpha$ accumulates in media conditioned by both cell types. Of those cells in the seminiferous epithelium, only peritubular cells appear to contain EGF/TGF- $\alpha$ receptors and to proliferate and form colonies in the presence of TGF- $\alpha$. As a working hypothesis, it seems reasonable to propose that TGF- $\alpha$ is synthesized and secreted by peritubular and Sertoli cells, and acts through autocrine/ paracrine mechanisms to induce and maintain critical interactions between the two cell types. These interactions presumably facilitate formation of the seminiferous epithelium and perhaps maintenance of adult spermatogenesis. Identifying and elucidating the pathways involved will be a major challenge for the future.

\section{Transforming growth factor $-\beta(T G F-\beta)$}

TGF- $\beta$, like TGF- $\alpha$, was identified by its ability to induce NRK cells to undergo transformation and colony formation (De Largo \& Todaro, 1978). The peptide is related to the activin and inhibin family, and acts as a growth-inhibiting factor for most cell types (Deuel, 1987). Interestingly, TGF$\beta$ is a potent desmoplastic agent, causing a marked increase in the formation of connective tissue, by stimulating the production and deposition of collagen and fibronectin (Roberts et al., 1986). Moreover, the presence of TGF- $\beta$ in bone tissues lends credence to the peptide's role as an autocrine regulator of bone formation (Centrella et al., 1987). These multifunctional properties of TGF$\beta$ suggest an involvement in the excessive deposition of extracellular matrix in the testes of patients with Kleinfelter's syndrome and the pluripotent nature of testicular teratomas.

Limited information is available concerning the expression and action of TGF- $\beta$ in the testes. TGF- $\beta$, when added to primary cultures of Leydig cells, reduced the number of hCG receptors $/ 10^{6}$ cells, without affecting the binding affinity of the ligand (Avallet et al., 1987). The effect was dosedependent within an $\mathrm{ED}_{50}$ of $\sim 100 \mathrm{pg}$ peptide $/ \mathrm{ml}$, and at maximal levels ( $1 \mathrm{ng} \mathrm{TGF}-\beta / \mathrm{ml}$ ) caused a $70 \%$ reduction in the number of hCG receptors, a $50 \%$ decrease in the hCG-induced cAMP, and a $60-70 \%$ decrement in testosterone production (Avallet et al., 1987). Also, pretreatment of Leydig cells with TGF- $\beta$ decreased the expected forskolin-induced increased in cAMP production, in the presence and absence of hCG, and actually enhanced the conversion of pregnenolone to testosterone. The peptide therefore appeared to be acting at multiple points in the steroidogenic pathway, by modifying the number of hCG receptors, the activity of the adenylate cyclase catalytic subunit, and influencing steps in steroid metabolism before the formation of pregnenolone (Avallet $e t$ al., 1987). These results suggest that TGF- $\beta$ plays an important role in regulating steroid metabolism. It will be critical, therefore, to determine whether TGF- $\beta$ is produced locally in the testes to exert autocrine/paracrine control mechanisms.

\section{Interleukin-1 (IL-1)}

IL- $1 \alpha$ and $-\beta$, previously referred to as lymphocyte-activating factor, are produced by macrophages and induce active proliferation of T-cells and B-cells to propagate an appropriate immune 
response (Table 1). The peptides are secreted by those macrophages activated in the vicinity of inflamed tissue (Oppenheimer et al., 1986). The proteins, both known pyrogens, are produced by various other cells in an acute-phase response to infection and injury. One major property of IL-1 is the ability to induce production of arachidonic metabolites, particularly prostaglandin $\mathrm{E}$, in a variety of cell types, including fibroblasts, chondrocytes and synovial cells (Dinarello, 1988). The IL-1s are synthesized as precursor proteins of $M_{\mathrm{r}} 31000$, and both are processed intracellularly to yield the active carboxy-terminal polypeptide of $M_{\mathrm{r}} 17000$ (Lomedico et al., 1984; March et al., 1985). The mature, biologically active, IL- $1 \alpha$ and IL-1 $\beta$, have similar $M_{\mathrm{r}}$ values but pI values of 5 and 7 , respectively. The two polypeptides, now available in recombinant forms, share only a low level of homology (Dinarello, 1988).

The testicular polypeptide is an IL-l $\alpha$-like growth factor. This IL-l $\alpha$ activity, based on the stimulation of $\left[{ }^{3} \mathrm{H}\right]$ thymidine incorporation into mouse thymocytes, is detectable in soluble fractions prepared from rat testes and spleen, but not in those from the heart, liver, kidney, prostate or ovary (Khan et al., 1987). Testicular IL-1 activity is localized entirely within the seminiferous tubules. Moreover, it accumulates to some extent in the medium of cultured seminiferous tubules, but not with interstitial cells or peritubular cells, from either normal or cryptorchid rats. The activity is expressed at increasing levels in rat testes during pubertal development and adulthood, a temporal pattern that is the inverse of SGF expression.

Functions of IL-1 $\alpha$ in testes have not yet been reported. Several possibilities are evident. First, testicular IL-1 $\alpha$ may be responsible for promoting cyclic phagocytic activity of Sertoli cells, to facilitate removal of the large numbers of residual bodies from the epithelium at spermiation. Second, the activity may be part of the immune surveillance system, poised to mediate suppression of autoimmune reactions and inflammatory responses. Third, it may be involved in promoting cell proliferation and metabolism, similar to the effects of IL-1 on fibroblasts (Postlethwaite et al., 1984), glial cells (Guilian \& Larchman, 1985), osteoblasts (Rifas et al., 1984) and chondrocytes (Madsen \& Soder, 1986). Fourth, IL-1 $\alpha$ may induce protein synthesis and arachidonic metabolites, possibly in differentiated Sertoli cells or advanced germ cells. Fifth, the peptide may regulate specific functions of interstitial macrophages, cells that are known to be in intimate contact with Leydig cells (Bergh, 1985) and be responsive to FSH. Studies on one or all of these proposed functions could identify new autocrine and paracrine pathways for regulating spermatogenesis.

\section{$\beta$-Nerve growth factor $(\beta-N G F)$}

The $\beta$ subunit, and the distinct $\alpha$ and $\gamma$ subunits, of NGF are stored as a heterotrimeric 7S complex in the submaxillary salivary glands of mice. Although subject to sexually dimorphic expression, the peptide normally has important functions in the development and maintenance of sensory and sympathetic neurones in the peripheral nervous system in mammals (Thoenen \& Barde, 1980). Surprisingly, the $\beta-N G F$ subunit or a closely related peptide has been shown to be present in spermatogenic cells and not detectable in the supporting somatic cells. In one case, $\beta$ NGF was localized by using immunofluorescence microscopy, with an affinity-purified, polyclonal antibody, to the cytoplasm of mouse spermatogonia, primary spermatocytes and spermatids (Olson et al., 1987). In a more recent study, mouse spermatogonia were reported to be negative for $\beta$-NGF (Ayer-LeLeviere et al., 1988). Three other proven anti-salivary $\beta$-NGF antibodies did not bind to spermatocytes and spermatids (Olson et al., 1987). These observations indicate that testicular $\beta$-NGF, while sharing at least one epitope with salivary $\beta$-NGF, lacks one or more other peptide domains, depending on the number of distinct epitopes recognized by the 3 polyclonal antibodies.

Differentiating mouse spermatocytes and spermatids were shown, based on a combination of Northern and in-situ hybridization analyses with an homologous $\beta$-NGF cDNA probe, to contain 1.5 and $1.3 \mathrm{~kb}$ mRNAs. Only the $1.3 \mathrm{~kb}$ transcript was expressed in mouse epididymis and rat testis. This smaller transcript was $\sim 200$ nucleotides longer than that expressed in the salivary gland, and 
was equivalent in size to a minor species detected previously in several other adult rat tissues, including brain and heart. The larger testicular $\beta$-NGF mRNAs were considered to have arisen from gene transcription occurring from an alternative start site or from differential splicing of a primary transcript, rather than differences in the degree of polyadenylation (Ayer-LeLeviere $e t$ al., 1988). Furthermore, a $3.4 \mathrm{~kb}$ mRNA encoding the receptor for $\beta$-NGF was present in the testis. The cellular location of the receptor remains to be determined.

Transcripts encoding $\beta$-NGF and the translated product(s) are therefore expressed in both primary spermatocytes and spermatids. The growth factor remains associated with spermatozoa throughout their maturation in the epididymis, and further peptides may be absorbed to the sperm surface from sources in the epididymal epithelium. The presence of $\beta$-NGF in spermatozoa and in prostatic secretions raises important questions concerning the role of this protein in sperm motility, particularly since $\beta$-NGF is a known chemoattractant for motile leucocytes. The possible relationship between $\beta$-NGF and the 'forward motility protein' also needs to be addressed carefully. This latter protein is produced by the epididymal epithelium, 'absorbed' to the sperm cell, and shifts the anarchic motility pattern to one that generates forward movement (Acott \& Hoskins, 1981).

\section{Discussion}

Growth factors, acting individually or in concert, will prove to be complex and sensitive regulators of testicular functions, whether these involve cells of interstitial, epithelial or seminal origin. Roles for multiple growth factors can be envisaged, based on the precise renewal of spermatogonial divisions, the co-ordinated growth among germ cells in neighbouring syncytia, the synchronized transit of spermatocyte syncytia across the occluding Sertoli cell junctions, and the complexity of the differentiative sequence of spermatogenesis. Existence of the Sertoli junctions portends a need for local factors to sustain essential cell functions in the avascular, adluminal/central environment of the seminiferous epithelium. Growth factors present in serum presumably act primarily, if not exclusively, on somatic and germ cells having receptors accessible to these polypeptides within the interstitial and peritubular regions. These would include endothelial, Leydig, macrophage, myoid, spermatogonial and Sertoli cells. The serum-derived growth factors, such as EGF and IGF-II, presumably have limited access to the central compartment of the epithelium, unless mechanisms are available to facilitate their translocation across the intervening cytoplasm of the Sertoli cells. By analogy, the movement of serum transferrin across the Sertoli cell into the immediate environment of the differentiating germ cells is thought to be essential for germ cell survival (Griswold et al., 1989).

Certain growth factors have been localized to or are known to be produced by Sertoli cells, including SGF, IGF-I, IL- $1 \alpha$, SCSGF and TGF- $\alpha$. These peptides may act on cells within the basal and/or peripheral compartments of the seminiferous epithelium, depending on the direction of vectorial secretion and the distribution of target cells with the appropriate receptors. Whereas some growth factors may act exclusively on cells located within the central compartment, others could interact with cells, both somatic and germinal, in the peripheral compartment, or on target cells located in more distal regions of the reproductive tract. Likewise, growth factors known to be expressed by germ cells, such as $\beta-\mathrm{NGF}$, may act on neighbouring somatic cells or on targets involved on the pathway to fertilization. Given that these trophic peptides generally act through autocrine and paracrine pathways, local concentrations of peptide and receptor expression by target cells must determine the induction of different pleiotypic responses.

Finally, the relationship between certain growth factors and cellular receptors with protooncogenes (Berridge, 1986; Hill et al., 1987) is an exciting area for future research on testicular functions. For example, the cis oncogene encodes platelet-derived growth factor and the erb $\beta$ protein is related to the EGF receptor. Other oncogenic proteins have been shown to possess activities associated with the transduction of growth factor actions. The p21 product of the v-ras gene exhibits 
GTP-binding activity, the $\mathrm{p} 60$ protein encoded by v-src is a membrane-bound tyrosine kinase, and $v$-mos encodes a cytoplasmic protein kinase. Growth factors also induce expression of c-fos and $c$-myc mRNAs following their interaction with the membrane receptors. The encoded proteins are presumed to be an intrinsic part of the cascade leading the expression of pleiotypic effects of growth factors. The many alternatives are exciting and surely will present major challenges to those bent on resolving the mechanisms and pleiotypic actions of known, and probably as yet unknown, growth factors having important effects on male gonadal function.

\section{Preparation of this review was funded by BIOCOL, INC.}

\section{References}

Acott, T.S. \& Hoskins, D.D. (1981) Bovine sperm forward motility protein: Binding to epididymal spermatozoa. Biol. Reprod. 24, 234-240.

Aoki, A. \& Fawcett, D.W. (1978) Is there a local feedback from the seminiferous tubules affecting activity of the Leydig cells? Biol. Reprod. 19, $144-158$.

Aoki, A. \& Massa, E.M. (1972) Subcellular compartmentation of free and esterified cholesterol in the interstitial cells of mouse testes. Am. J. Anat. 134, 239-261.

Ascoli, M. (1981) Regulation of gonadotropin receptors and gonadotropin responses in a clonal strain of Leydig tumor cells by epidermal growth factor. $J$. biol. Chem. 256, 179-183.

Avallet, O., Vigier, M., Perrard-Sapori, M.H. \& Saez, J.M. (1987) Transforming growth factor $\beta$ inhibits Leydig cell functions. Biochem. Biophys. Res. Commun. 146, 575-581.

Ayer-LeLievre, C., Olson, L., Ebendal, T., Hallbook, F. \& Persson, H. (1988) Nerve growth factor mRNA and protein in the testis and epididymis of the mouse and rat. Proc. natn. Acad. Sci. U.S.A. 85, 2628-2632.

Baird, A., Esch, F., Gospodarowicz, D. \& Guillemin, R. (1985) Retina- and eye-derived endothelial cell growth factors: partial molecular characterization and identity with acidic and basic fibroblast growth factors. Biochemistry, N.Y. 24, 7855-7860.

Barni, T., Orlando, C., Caldini, A.L., Casano, R., Chelo, E., Forti, G. \& Serio, M. (1987) Radioimmunoassayable somatomedin $\mathrm{C}$ in seminal plasma of azoospermic patients. Int. J. Androl. 10, 457-462.

Baxter, R.C. (1986) The somatomedins: insulin-like growth factors. Adv. clin. Chem. 25, 49-115.

Baxter, R.C., Martin, J.L. \& Handelsman, D.J. (1984) Identification of human semen Insulin-like growth factor-I/somatomedin-C immunoreactivity and binding protein. Acta endocr., Copenh. 106, 420-427.

Bellvé, A.R. (1979) The molecular biology of mammalian spermatogenesis. Oxford Rev. Reprod. Biol. 1, $159-261$.

Bellvé, A.R. \& Feig, L.A. (1984) Cell proliferation in the mammalian testis: Biology of the seminiferous growth factor (SGF). Recent Prog. Horm. Res. 40, $531-567$.

Benahmed, M., Morera, A.H., Chauvin, M.C. \& de Peretti, E. (1987) Somatomedin C/insulin-like growth factor 1 as a possible intratesticular regulator of Leydig cell activity. Molec. cell. Endocrin. 50, 69-77.
Bergh, A. (1985) Effect of cryptorchidism on the morphology of testicular macrophages: evidence for a Leydig cell-macrophage interaction. Int. J. Androl. 8, 86-96.

Bernier, M., Chatelain, P., Mather, J.P. \& Saez, J.M. (1966) Regulation of gonadotropin receptors, gonadotropin responsiveness, and cell multiplication by somatomedin-C and insulin in cultured pig Leydig cells. J. cell. Physiol. 129, 257-263.

Berridge, M.J. (1986) Growth factors, oncogenes and inositol lipids. Cancer Surveys 55, 413430.

Böhlen, P., Esch, F., Baird, A., Jones, K.L. \& Gospodarowicz, D. (1985) Human brain fibroblast growth factor: isolation and partial chemical characterization. Fedn Eur. Biochem. Soc. Lett. 185, 177-181.

Borland, K., Mita, M., Oppenheimer, C.L., Blinderman, L.A., Massague, J., Hall, P.F. \& Czech, M.P. (1984) The actions of insulin-like growth factors I and II on cultured Sertoli cells. Endocrinology 114, 240-246.

Bringman, T.S., Lindquist, P.B. \& Derynck, R. (1987) Different transforming growth factor- $\alpha$ species are derived from a glycosylated and palmitoylated transmembrane precursor. Cell 48, 429-440.

Brown, K.D., Blakeley, D.M., Henville, A. \& Setchell, B.P. (1982) Rete testis fluid contains a growth factor for cultured fibroblasts. Biochem. Biophys. Res. Commun. 105, 391-397.

Buch, J.P., Lamb, D.J., Lipshultz, L.I. \& Smith, R.G. (1988) Partial characterization of a unique growth factor secreted by human Sertoli cells. Fert. Steril. 49, 658-664.

Burgess, W.H., Mehlman, T., Friesel, R., Johnson, W.V. \& Maciag, T. (1985) Multiple forms of endothelial cell growth factor: Rapid isolation and biological and chemical characterization. J. biol. Chem. 260, 11389-11392.

Casella, S.J., Smith, E.P., Van Wyk, J.J., Joseph, D.R., Hynes, M.A., Hoyt, E.C. \& Lund, P.K. (1987) Isolation of rat testis cDNAs encoding an insulin-like growth factor I precursor. DNA 6, 325-330.

Centrella, M., McCarthy, T.L. \& Canalis, E. (1987) Transforming growth factor $\beta$ is a bifunctional regulator of replication and collagen synthesis in osteoblast-enriched cell cultures from fetal rat bone. J. biol. Chem. 262, 2869-2874.

Chatelain, P.G., Naville, D. \& Saez, J.M. (1987) Somatomedin-C/insulin-like growth factor I-like material secreted by Sertoli cells in vitro: characterization and 
regulation. Biochem. Biophys. Res. Commun. 146, $1009-1017$.

Christensen, A.K. \& Peacock, K.C. (1980) Increase in Leydig cell number in testes of adult rats treated chronically with an excess of human chorionic gonadotropin. Biol. Reprod. 12, 368-382.

Clermont, Y. (1972) Kinetics of spermatogenesis in mammals: seminiferous epithelium cycle and spermatogonial renewal. Physiol. Rev. 52, 198-236.

Coffey, R.J., Jr, Derynck, R., Wilcox, J.N., Bringman, T.S., Goustin, A.S., Moses, H.L. \& Pittelkow, M.R. (1987) Production and auto-induction of transforming growth factor- $\alpha$ in human keratinocytes. Nature, Lond. 328, 817-820.

De Larco, J.E. \& Todaro, G.J. (1978) Growth factors from murine sarcoma virus transformed cells. Proc. natn. Acad. Sci. U.S.A. 75, 4001-4005.

De Mellow, J.S.M., Handelsman, D.J. \& Baxter, R.C. (1987) Short-term exposure to insulin-like growth factors stimulates testosterone production by testicular interstitial cells. Acta endocr., Copenh. 115, 483489.

D'Ercole, A.J., Stiles, A.D. \& Underwood, L.E. (1984) Tissue concentrations of somatomedin C: further evidence for multiple sites of synthesis and paracrine or autocrine mechanisms of action. Proc. natn. Acad. Sci. U.S.A. 81, 935-939.

de Reviers, M., Hochereau-de Reviers, M.T., Blanc, M.R., Brillard, P., Courot, M. \& Pelletier, J. (1980) Control of Sertoli and germ cell populations in the cock and sheep testes. Reprod. Nutr. Develop. 20, 241-249.

Derynck, R. (1986) Transforming growth factor- $\alpha$ : structure and biological activities. J. Cell Biochem. 32, 293-304.

Deuel, T.F. (1987) Polypeptide growth factors: roles in normal and abnormal cell growth. Ann. Rev. Cell Biol. 3, 443-492.

Dinarello, C.A. (1988) Interleukin-1. Digest. Dis. Sci. 33, 25S-35S.

Dym, M. \& Clermont, Y. (1970) Role of spermatogonia in the repair of the seminiferous epithelium following X-irradiation of the rat testis. Am. J. Anat. 128, 265282 .

Elson, S.D., Browne, C.A. \& Thorburn, G.D. (1984) Identification of growth factor-like activity in human male reproductive tissues and fluids. J. clin. Endocr. Metab. 58, 589-594.

Esch, F., Ueno, N., Baird, A., Hill, F., Denoroy, L., Ling, N., Gospodarowicz, D. \& Guillemin, R. (1985) Primary structure of bovine brain acidic fibroblast growth factor. Biochem. Biophys. Res. Commun. 133, $554-562$.

Erickson, B.H. (1978) Effect of continuous gammaradiation on the stem and differentiating spermatogonia of the adult rat. Mutation Res. 52, 117-128.

Feig, L.A., Bellvé, A.R., Horbach-Erickson, N. \& Klagsbrun, M. (1980) Sertoli cells contain a mitogenic polypeptide. Proc. natn. Acad. Sci. U.S.A. 77, 4774-4778.

Feig, L.A., Klagsbrun, M. \& Bellvé, A.R. (1983) Mitogenic polypeptide of the mammalian seminiferous epithelium: biochemical characterization and partial purification. J. Cell Biol. 97, 1435-1443.
Gimenez-Gallego, G., Rodley, J., Bennett, C., RiosCandelore, M., Di Salvo, J. \& Thomas, K. (1985) Brain-derived acidic fibroblast growth factor: Complete amino acid sequence and homologies. Science, N. Y. 230, 1385-1388.

Gospodarowicz, D., Cheng, J., Lui, G.M., Baird, A. \& Böhlen, P. (1984) Isolation of brain fibroblast growth factor by heparin-sepharose affinity chromatography: Identity with pituitary fibroblast growth factor. Proc. natn. Acad. Sci. U.S.A. 81, 6963-6967.

Gospodarowicz, D., Cheng, J., Liu, G.M., Fujii, K.D., Baird, A. \& Bohlen, P. (1985) Fibroblast growth factor in the human placenta. Biochem. Biophys. Res. Commun. 128, $554-562$.

Gospodarowicz, D., Baird, A., Cheng, J., Liu, G.M., Esch, F. \& Böhlen, P. (1986) Isolation of fibroblast growth factor from bovine adrenal gland: physiochemical and biological characterization. Endocrinology 118, 82-90.

Griswold, M.D., Solari, A., Tung, P. \& Fritz, I.B. (1974) Stimulation by FSH of DNA synthesis and mitosis in cultured Sertoli cells prepared from testis of immature rats. Molec. cell. Endocr. 3, 151-165.

Griswold, M.D., Morales, C. \& Sylvester, S. (1989) Molecular biology of the Sertoli cell. Oxford Rev. Reprod. Biol. 10, 124-161.

Guilian, D. \& Larchman, L.B. (1985) Interleukin-1 stimulation of astroglial proliferation after brain injury. Science, N.Y. 228, 497-499.

Hall, K., Ritzen, E.M., Johnsonbaugh, R.E. \& Parvinen, M. (1983) Pubertal rise of immunoreactive somatomedin and its eventual source. In Insulin-like Growth Factors/Somatomedins. Basic Biochemistry, Biology, Clinical Importance, pp. 611-614. Ed. E. M. Spencer. Walter de Gruyter Co., New York.

Handelsman, D.J., Spaliviero, J.A., Scott, C.D. \& Baxter, R.C. (1985) Identification of insulin-like growth factor-I and its receptors in the rat testis. Acta endocr., Copenh. 109, 543-549.

Harper, G.P., Glanville, R.W. \& Thoenen, H. (1982) The purification of nerve growth factor from bovine seminal plasma. Biochemical characterization and partial amino acid sequence. J. biol. Chem. 257, 8541-8548.

Hill, D.J., Strain, A.J. \& Milner, R.D.G. (1987) Growth factors in embryogenesis. Oxford Rev. Reprod. Biol. 9, 398-455.

Hochereau-de Reviers, M.-T., Courot, M., Perreau, C. \& Pisselet, C. (1978) Sertoli cells and development of seminiferous epithelium. Annls Biol. anim. Biochim. Biophys. 18, 573-583.

Holmes, S.D., Spotts, G. \& Smith, R.G. (1986) Rat Sertoli cells secrete a growth factor that blocks epidermal growth factor binding to its receptor. J. biol. Chem. 261, 4076-4080.

Huckins, C. (1978) The morphology and kinetics of spermatogonial degeneration in normal adult rats: an analysis using a simplified classification of the germinal epithelium. Anat. Rec. 190, 905-926.

Huckins, C. \& Clermont, Y. (1968) Evolution of gonocytes in the rat testis during late embryonic and postnatal life. Archs Anat. Histol. Embryol. 51, 343-354.

Huckins, C. \& Cunningham, G.R. (1975) Behavior of spermatogonia in hypophysectomized adult rats. Anat. Rec. 181, 380. 
Irons, M.J. \& Clermont, Y. (1979) Spermatogonial chalones: effect on the phases of the cell cycle of type A spermatogonia in the rat. Cell Tissue Kinet. 12, 425-433.

Jackson, N.C., Jackson, H., Shanks, J.H., Dixon, J.S. \& Lendon, R.G. (1985) Study using in vivo binding of ${ }^{125} \mathrm{I}$-labelled hCG, light and electron microscopy of the repopulation of rat Leydig cells after destruction due to administration of ethylene-1,2-dimethanesulphonate. J. Reprod. Fert. 76, 1-10.

Jaillard, C., Chatelain, P.G. \& Saez, J.M. (1987) In vitro regulation of pig Sertoli cell growth and function: effects of fibroblast growth factor and somatomedinC. Biol. Reprod. 37, 665-674.

Kasselberg, A.G., Orth, D.N., Gray, M.E. \& Stahlman, M.T. (1985) Immunocytochemical localization of human epidermal growth factor/urogastrone in several human tissues. J. Histochem. Cytochem. 33, 315-322.

Kasson, B.G. \& Hsueh, A.J.W. (1987) Insulin-like growth factor-I augments gonadotrophin-stimulated androgen biosynthesis by cultured rat testicular cells. Molec. cell. Endocrin. 52, 27-34.

Kerr, J.B. \& Donachie, K. (1986) Regeneration of Leydig cells in unilaterally cryptorchid rats: evidence for stimulation by local testicular growth factors. Cell Tissue Res. 245, 649-655.

Kerr, J.B., Bartlett, J.M.S., Donachie, K. \& Sharpe, R.M. (1987) Origin of regenerating Leydig cells in the testes of the adult rat. An ultrastructural, morphometric and hormonal assay study. Cell Tissue Res. 249, 367-377.

Khan, S.A., Söder, O., Syed, V., Gustafsson, K., Lindh, M. \& Ritzen, E.M. (1987) The rat produces large amounts of an interleukin-1-like factor. Int. $J$. Androl. 10, 495-503.

Lee, D.C., Rochford, R.M., Todaro, G.J. \& Villareal, L.P. (1985) Developmental expression of rat transforming growth factor- $\alpha$ mRNA. Molec. cell. Biol. $\mathbf{5}$, $3644-3646$.

Lin, T., Haskel, J., Vinson, N. \& Terracio, L. (1986) Direct stimulatory effects of insulin-like growth factor-I on Leydig cell steroidogenesis in primary culture. Biochem. Biophys. Res. Commun. 137, 950-956.

Lobel, P., Dahms, N.M., Breitmeyer, J., Chirgwin, J.M. \& Kornfeld, S. (1987) Cloning of the bovine 215-kDa cation-independent mannose 6-phosphate receptor. Proc. natn. Acad. Sci. U.S.A. 84, $2233-2237$.

Lomedico, P.T., Gubler, U., Hellman, C.P., Dukovich, M., Giri, J.G., Pan, Y.E., Collier, K., Semionow, R., Chua, A.O. \& Mizel, S.B. (1984) Cloning and expression of murine interleukin-1 in Escherichia coli. Nature, Lond. 312, 458-462.

Madsen, K. \& Söder, O. (1986) Interleukin-1 stimulates the proliferation of rat epiphyseal chondrocytes in vitro. Proc. 6th Int. Congr. Immunology, Toronto, Abstr.

Magre, S. \& Jost, A. (1980) The initial phases of testicular organogenesis in the rat: an electron microscope study. Archs Anat. microsc. Morph. exp. 69, 297-318.

March, C.T., Mosley, B., Larsin, A., Cerretti, D.P., Braedt, G., Price, V., Gillis, S., Henney, C.S., Kronheim, S.R., Grabstein, K., Conlon, P.J., Hopp, T.P. \& Cosman, D. (1985) Cloning, sequence and expression of two distinct human interleukin-1 complementary DNAs. Nature, Lond. 315, 641-647.
Massague, J. \& Czech, M.P. (1982) The subunit structures of two distinct receptors for insulin-like growth I and II and their relationship to the insulin receptor. J. biol. Chem. 257, 5038-5045.

Mather, J.P. (1980) Establishment and characterization of two distinct mouse testicular epithelial cell lines. Biol. Reprod. 23, 243-251.

Mather, J.P. \& Phillips, D.M. (1984) Primary culture of testicular somatic cells. In Methods for Serum-free Culture of Cells of the Endocrine System, pp. 29-45. A. R. Liss, New York.

Mita, M. \& Hall, P.P. (1982) Metabolism of round spermatids from rats: lactate as the preferred substrate. Biol. Reprod. 26, 445-455.

Mita, M., Price, J.M. \& Hall, P.F. (1982) Stimulation by FSH of synthesis of lactate by Sertoli cells from rat testis. Endocrinology 110, 1535-1541.

Mita, M., Borland, K., Price, M.J. \& Hall, P.F. (1985) The influence of insulin and insulin-like growth factor-I on hexose transport by Sertoli cells. Endocrinology 116, 987-992.

Morgan, D.O., Edman, J.C., Standring, D.N., Fried, V.A., Smith, M.C., Roth, R.A. \& Rutter, W.J. (1987) Insulinlike growth factor II receptor as a multi-functional binding protein. Nature, Lond. 329, 301-307.

Murphy, L.J., Bell, G.I. \& Friesen, H.G. (1987) Tissue distribution of insulin-like growth factor I and II messenger ribonucleic acid in the aduit rat. Endocrinology 120, 1279-1282.

Nagy, F. (1972) Cell division kinetics and DNA synthesis in the immature Sertoli cells of the rat testis. $J$. Reprod. Fert. 28, 389-395.

O'Brien, D.A., Gable, C.A. \& Eddy, B.M. (1988) Mannose 6-phosphate receptor-mediated endocytosis in isolated mouse spermatogenic cells. Biol. Reprod. 38 (Suppl. 1), p. 141, Abstr.

Olson, L., Ayer-LeLievre, C., Ebendal, T. \& Seiger, A. (1987) Nerve growth factor-like immunoreactivities in rodent salivary glands and testes. Cell Tissue Res. 248, 275-286.

Oonk, R.B. (1987) Effects of FSH, insulin and IGF-I on rat Sertoli cells. In Proefschrift, pp. 1-159. Erasmus University, Rotterdam.

Oonk, R.B. \& Grootegoed, J.A. (1988) Insulin-like growth factor I (IGF-I) receptors on Sertoli cells from immature rats and age-dependent testicular binding of IGF-I and insulin. Molec. cell. Endocrin. 55, 33-43.

Oppenheimer, J.J., Kovacs, E.J., Matsushima, K. \& Durum, S.K. (1986) There is more than one interleukin I. Immunology Today 7, 45-56.

Orth, J. (1982) Proliferation of Sertoli cells in fetal and postnatal rats: a quantitative autoradiographic study. Anat. Rec. 203, 485-492.

Postlethwaite, A.E., Lachman, L.B. \& Kang, A.H. (1984) Induction of fibroblast proliferation by interleukin-1 derived from human monocytic leukemia cells. Arthritis Rheumatism 27, 995-1000.

Rifas, L., Shen, V., Mitchell, K. \& Peck, W.A. (1984) Macrophage-derived growth factor for osteoblastlike cells and chondrocytes. Proc. natn. Acad. Sci. U.S.A. 81, 4558-4563.

Roberts, A.B., Sporn, M.B., Assoian, R.K., Smith, J.M., Roche, N.S., Wakefield, L.M., Heine, U.I., Liotta, 
L.A., Falanga, V., Kehrl, J.H. \& Fauci, A.S. (1986) Transforming growth factor type $\beta$ : rapid induction of fibrosis and angiogenesis in vivo and stimulation of collagen formation in vitro. Proc. natn. Acad. Sci. U.S.A. 83, $4167-4171$.

Samsoonder, J., Kobrin, M.S. \& Kudlow, J.E. (1986) $\alpha$-Transforming growth factor secreted by untransformed bovine anterior pituitary cells in culture. $J$. biol. Chem. 261, 14408-14412.

Skinner, M.K. \& Griswold, M.D. (1983) Multiplication stimulating activity (MSA) can substitute for insulin to stimulate the secretion of testicular transferrin by cultured Sertoli cells. Cell Biol. Int. Rep. 7, 441-446.

Skinner, M.K., Takacs, K. \& Coffey, R.J. (1989) Transforming growth factor-alpha gene expression and action in the seminiferous tubule: peritubular cellSertoli cell interactions. Endocrinology (in press).

Smith, E.P., Svoboda, M.E., Van Wyk, J.J., Kierszenbaum, A.L. \& Tres, L.L. (1987) Partial characterization of a somatomedin-like peptide from the medium of cultured rat Sertoli cells. Endocrinology 120, 186-193.

Sporn, M.B. \& Todaro, G.J. (1980) Autocrine secretion and malignant transformation of cells. New Eng. $J$. Med. 303, 878-880.

Steinberger, A. \& Steinberger, E. (1971) Replication pattern of Sertoli cells in maturing rat testis in vivo and in organ culture. Biol. Reprod. 4, 84-87.

Taylor, J.E., Scott, C.D. \& Baxter, R.C. (1987) Comparison of receptors for insulin-like growth factor II from various tissues. J. Endocr. 115, 35-41.

Thoenen, H. \& Barde, Y.-A. (1980) Physiology of nerve growth factor. Physiol. Rev. 60, 1284-1339.
Tres, L.L., Smith, E.P., Van Wyck, J.J. \& Kierszenbaum, A.L. (1986) Immunoreactive sites and accumulation of somatomedin- $C$ in rat Sertoli-spermatogenic cell co-cultures. Expl Cell Res. 162. 33-50.

Tsutumi, O., Kurachi, H. \& Oka, T. (1986) A physiological role of epidermal growth factor in male reproductive function. Science, N.Y. 233, 975-977.

Ueno, N., Baird, A., Esch, F., Ling, N. \& Guillemin, R. (1987) Isolation and partial characterization of basic fibroblast growth factor from bovine testis. Molec. cell. Endocrin. 49, 189-194.

Unni, E., Kesari, K.V. \& Rao, M.R.S. (1984) Effect of vitamin A deprivation on the mitogenic factor activity in the rat testes. Biochem. Biophys. Res. Commun. 125, 454-462.

Vannelli, B.G., Natali, A., Barni, T., Serio, M., Orlando, C. \& Balboni, G. (1988) Insulin-like growth factor-I (IGF-I) and IGF-I receptor in human testis: An immunohistochemical study. Fert. Steril. 49, 666669.

Welsh, T.H. \& Hsueh, A.J.W. (1982) Mechanism of the inhibitory action of epidermal growth factor on testicular androgen biosynthesis in vitro. Endocrinology 110, 1498-1506.

Zamboni, L. \& Upadhyay, S. (1982) The contribution of the mesonephros to the development of the sheep fetal testis. Am. J. Anat. 165, 339-356.

Zhan, X., Bates, B., Hu, X. \& Goldfarb, M. (1988) The human FGF-5 oncogene encodes a novel protein related to fibroblast growth factors. Molec. cell. Biol. 8, 3487-3495. 